\title{
Comparison of Nonheme Manganese- and Iron-Containing Flavone Synthase Mimics
}

\author{
Dóra Lakk-Bogáth ${ }^{1}$, Natalija Pantalon Juraj ${ }^{2}$, Bashdar I. Meena ${ }^{1}$, Berislav Perić ${ }^{2}$, Srećko I. Kirin ${ }^{2}(\mathbb{D}$ \\ and József Kaizer $1, *$ (D) \\ 1 Research Group of Bioorganic and Biocoordination Chemistry, University of Pannonia, \\ H-8201 Veszprém, Hungary; lakkd@almos.uni-pannon.hu (D.L.-B.); bashdarismael@gmail.com (B.I.M.) \\ 2 Division of Materials Chemistry, Ruđer Bošković Institute, Bijenička c. 54, HR-10000 Zagreb, Croatia; \\ Natalija.Pantalon.Juraj@irb.hr (N.P.J.); Berislav.Peric@irb.hr (B.P.); srecko.kirin@irb.hr (S.I.K.) \\ * Correspondence: kaizer@almos.uni-pannon.hu; Tel.: +36-88-62-4720
}

Citation: Lakk-Bogáth, D.; Juraj, N.P.; Meena, B.I.; Perić, B.; Kirin, S.I.; Kaizer, J. Comparison of Nonheme Manganese- and Iron-Containing Flavone Synthase Mimics. Molecules 2021, 26, 3220. https://doi.org/ $10.3390 /$ molecules 26113220

Academic Editors: Jadwiga Handzlik and Katarzyna Kucwaj-Brysz

Received: 7 May 2021

Accepted: 26 May 2021

Published: 27 May 2021

Publisher's Note: MDPI stays neutral with regard to jurisdictional claims in published maps and institutional affiliations.

Copyright: (c) 2021 by the authors. Licensee MDPI, Basel, Switzerland. This article is an open access article distributed under the terms and conditions of the Creative Commons Attribution (CC BY) license (https:// creativecommons.org/licenses/by/ $4.0 /)$.

\begin{abstract}
Heme and nonheme-type flavone synthase enzymes, FS I and FS II are responsible for the synthesis of flavones, which play an important role in various biological processes, and have a wide range of biomedicinal properties including antitumor, antimalarial, and antioxidant activities. To get more insight into the mechanism of this curious enzyme reaction, nonheme structural and functional models were carried out by the use of mononuclear iron, $\left[\mathrm{Fe}^{\mathrm{II}}\left(\mathrm{CDA}-\mathrm{BPA}^{*}\right)\right]^{2+}(6)[\mathrm{CDA}-$ $\mathrm{BPA}=N, N, N^{\prime}, N^{\prime}$-tetrakis-(2-pyridylmethyl)-cyclohexanediamine], [Fe $\left.\mathrm{Fe}^{\mathrm{II}}\left(\mathrm{CDA}-\mathrm{BQA}^{*}\right)\right]^{2+}(5)[\mathrm{CDA}$ $\mathrm{BQA}=N, N, N^{\prime}, N^{\prime}$-tetrakis-(2-quinolilmethyl)-cyclohexanediamine], [ $\left.\mathrm{Fe}^{\mathrm{II}}(\mathrm{Bn}-\mathrm{TPEN})\left(\mathrm{CH}_{3} \mathrm{CN}\right)\right]^{2+}$ (3) [Bn-TPEN = N-benzyl- $N, N^{\prime}, N^{\prime}$-tris(2-pyridylmethyl)-1,2-diaminoethane], $\left[\mathrm{Fe}^{\mathrm{IV}}(\mathrm{O})(\mathrm{Bn}-\mathrm{TPEN})\right]^{2+}(9)$, and manganese, $\left[\mathrm{Mn}^{\mathrm{II}}\left(\mathrm{N} 4 \mathrm{Py}^{*}\right)\left(\mathrm{CH}_{3} \mathrm{CN}\right)\right]^{2+}(2)\left[\mathrm{N} 4 \mathrm{Py}{ }^{*}=\mathrm{N}, \mathrm{N}\right.$-bis(2-pyridylmethyl)-1,2-di(2-pyridyl) ethylamine $)],\left[\mathrm{Mn}^{\mathrm{II}}(\mathrm{Bn}-\mathrm{TPEN})\left(\mathrm{CH}_{3} \mathrm{CN}\right)\right]^{2+}(4)$ complexes as catalysts, where the possible reactive intermediates, high-valent $\mathrm{Fe}^{\mathrm{IV}}(\mathrm{O})$ and $\mathrm{Mn}^{\mathrm{IV}}(\mathrm{O})$ are known and well characterised. The results of the catalytic and stoichiometric reactions showed that the ligand framework and the nature of the metal cofactor significantly influenced the reactivity of the catalyst and its intermediate. Comparing the reactions of $\left[\mathrm{Fe}^{\mathrm{IV}}(\mathrm{O})(\mathrm{Bn}-\mathrm{TPEN})\right]^{2+}(\mathbf{9})$ and $\left[\mathrm{Mn}^{\mathrm{IV}}(\mathrm{O})(\mathrm{Bn}-\mathrm{TPEN})\right]^{2+}(\mathbf{1 0})$ towards flavanone under the same conditions, a 3.5-fold difference in reaction rate was observed in favor of iron, and this value is three orders of magnitude higher than was observed for the previously published $\left[\mathrm{Fe}^{\mathrm{IV}}(\mathrm{O})\left(\mathrm{N} 2 \mathrm{Py} 2 \mathrm{Q}^{*}\right)\right]^{2+}$ [N,N-bis(2-quinolylmethyl)-1,2-di(2-pyridyl)ethylamine] species.
\end{abstract}

Keywords: flavone synthase; iron(IV)-oxo; manganese(IV)-oxo; oxidation; kinetic studies

\section{Introduction}

Flavones are low molecular weight phytochemicals that play an important role in various biological processes and have a positive impact on our health [1]. Due to their wide range of biological activities (malaria, anti-cancer, anti-diabetes, asthma, antiviral, antioxidant, anti-microbial, anti-ulcer, anti-inflammation, cardiovascular activity, neuroprotection, etc.) their syntheses have become important goals of medicinal and bioorganic chemists [2-8]. Flavones can be synthesised by various methods including Baker-Venkataraman-rearrangement from $o$-hydroxyacetophenone [1], and oxidation of flavanones using various stoichiometric reagents such as $\mathrm{DMSO} / \mathrm{I}_{2}$ [9], $\mathrm{SeO}_{2}$ [10], 2,3dichloro-5,6-dicyano-1,4-benzoquinone [11], thallium salts [12] and manganese acetate [13]. The oxidation of flavanones by heme and nonheme iron-dependent enzymes is one of the most important steps during the biosynthesis of flavones. High-valent oxoiron(IV) intermediates as key oxidants are well-established in both heme and nonheme enzymes, including cytochrome P450, bovine liver catalase (BLC) $[14,15]$, flavone synthase II (FS II) [16-20], pterin-dependent phenylalanine hydroxylase [21], and $\alpha$-keto acid-dependent dioxygenases (taurine dioxygenase, TauD [22-24] and flavone synthase I, FS I) [25-28], 
and their synthetic biomimetic models. Interestingly, two main classes of flavone synthase enzymes are known, FS I and FS II, with totally different active sites and catalytic mechanisms (Scheme 1). The majority of flavone synthase enzymes (FS II) contain iron(III)protoporphyrin $\left(\mathrm{PFe}^{\mathrm{III}}\right)$ as a prosthetic group with $\left(\mathrm{P}^{+\bullet}\right) \mathrm{Fe}^{\mathrm{IV}}=\mathrm{O}$ oxidant $(\mathrm{CYP} 93 \mathrm{~B})$, and the reaction proceeds via the formation of 2-hydroxyflavanone (monooxygenase activity) and its subsequent dehydration into the flavones [29]. In contrast, FS I enzymes utilise nonheme mononuclear iron(II)-2-oxoglutarate $\left(\mathrm{Fe}^{\mathrm{II}} / 2-\mathrm{OG}\right)$ as a prosthetic group where the reaction can be described by oxoiron(IV) mediated, direct non-concerted 2,3-desaturation without 2-hydroxyflavanone formation [30].

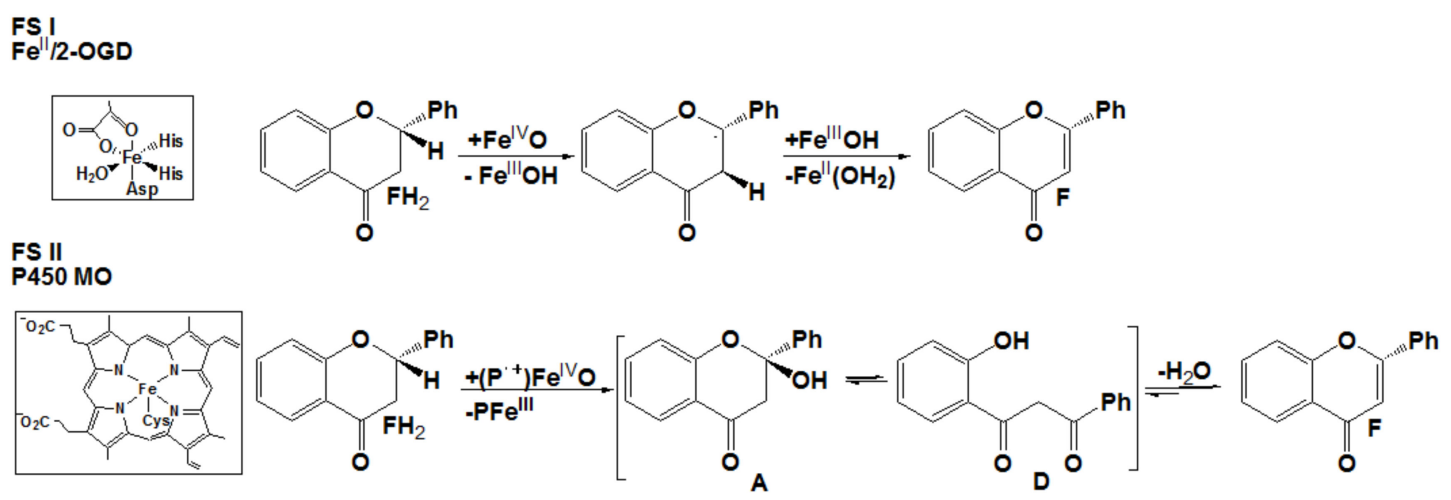

Scheme 1. Oxidation of flavanone by heme and nonheme flavone synthases, FS I and FS II.

Since flavanone itself is a chiral molecule, oxidative kinetic resolution (OKR) of racemic flavanones can also be performed with a chiral iron catalyst and oxoiron(IV) intermediates. Increasing interest in the region and stereoselective metal-based reactions to generate new stereogenic centres in a highly diastereoselective and/or enantioselective fashion inspires the search for biomimetic oxidation catalysts. Intermediates of this type were observed in catalytic oxidation systems and synthetised and identified indirectly by the use of iron precursor complexes with various chiral and achiral aminopyridine ligands [31-36].

In the present work, we carried out stoichiometric and catalytic flavanone oxidation reactions with spectroscopically well-characterised nonheme oxoiron(IV) intermediates compared to their analogous oxomanganese(IV) compounds, $\left[\mathrm{Fe}^{\mathrm{IV}}(\mathrm{O})(\mathrm{Bn}-\mathrm{TPEN})\right]^{2+}(9)[37,38]$, $\left[\mathrm{Fe}^{\mathrm{IV}}(\mathrm{O})(\mathrm{CDA}-\mathrm{BPA})\right]^{2+}(\mathbf{1 1}),\left[\mathrm{Mn}^{\mathrm{IV}}(\mathrm{O})\left(\mathrm{N} 4 \mathrm{Py}^{*}\right)\right]^{2+}(\mathbf{8})[39],\left[\mathrm{Mn}^{\mathrm{IV}}(\mathrm{O})(\mathrm{Bn}-\mathrm{TPEN})\right]^{2+}(\mathbf{1 0})[40]$ and their precursor complexes, $\left[\mathrm{Fe}^{\mathrm{II}}(\mathrm{Bn}-\mathrm{TPEN})\left(\mathrm{CH}_{3} \mathrm{CN}\right)\right]^{2+}(3),\left[\mathrm{Fe}^{\mathrm{II}}\left(\mathrm{CDA}^{\mathrm{B}}-\mathrm{BQA}^{*}\right)\right]^{2+}(5)$, $\left[\mathrm{Fe}^{\mathrm{II}}\left(\mathrm{CDA}-\mathrm{BPA}^{*}\right)\right]^{2+}(6)[41],\left[\mathrm{Mn}^{\mathrm{II}}\left(\mathrm{N} 4 \mathrm{Py}^{*}\right)\left(\mathrm{CH}_{3} \mathrm{CN}\right)\right]^{2+}(2)[39],\left[\mathrm{Mn}{ }^{\mathrm{II}}(\mathrm{Bn}-\mathrm{TPEN})\left(\mathrm{CH}_{3} \mathrm{CN}\right)\right]^{2+}$ (4) (Scheme 2) [40]. To the best of our knowledge, this study provides the first mechanistic details of oxomanganese(IV)-mediated flavanone oxidation compared to their analogous oxoiron(IV)-mediated systems, which may serve as a functional model of FS enzymes. Based on the detected intermediary products, the catalysis of double-bond formation is suggested to take place in two steps, namely by the monohydroxylation of the substrate, and then the elimination of water from the intermediary 2-hydroxyflavanone. This mechanism is different from the hitherto known FS I enzyme, but it is consistent with other 2-oxoglutarate-dependent enzymes, and the heme iron-dependent flavone synthase II. 


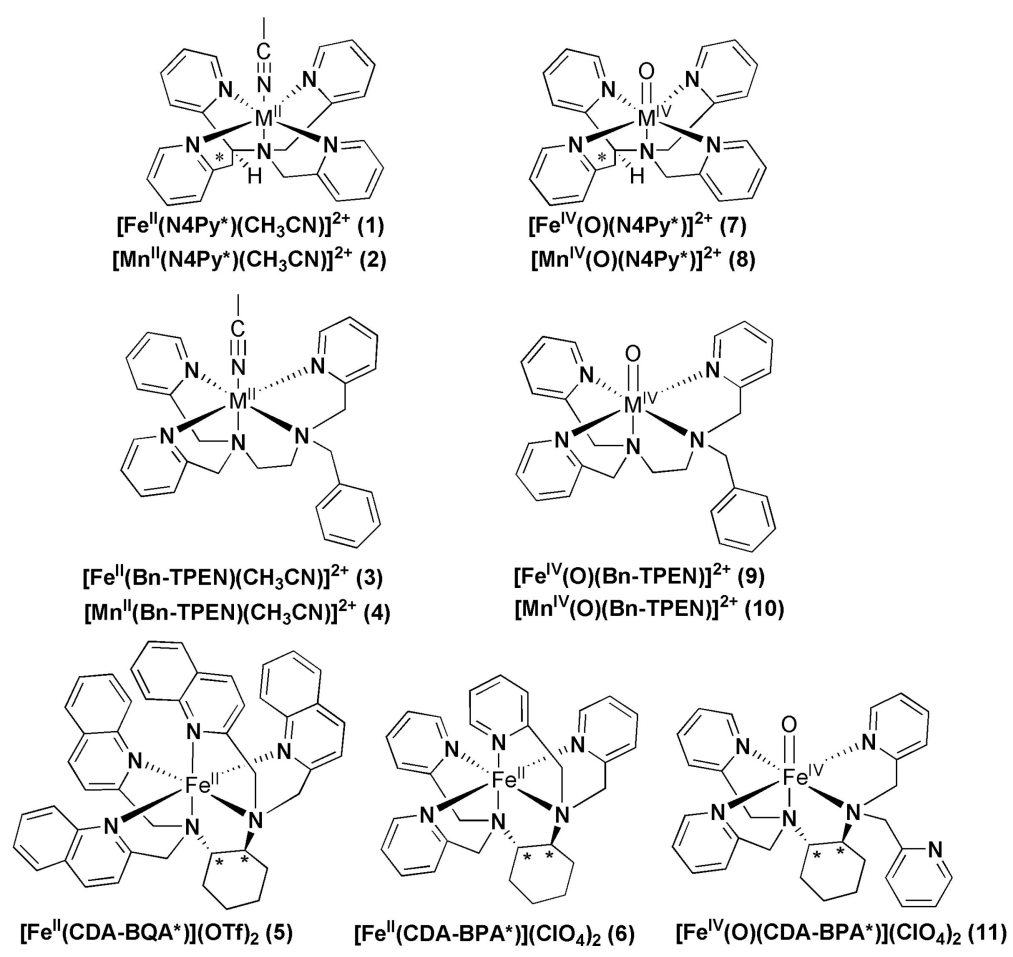

Scheme 2. Oxoiron(IV) and oxomanganese(IV) complexes with their iron(II) and manganese(II) precursor complexes were used in this study.

\section{Results and Discussion}

2.1. Nonheme Iron and Manganese-Containing Biomimics of the Flavone Synthase Enzyme

The use of well-chosen ligands made it possible to prepare, spectroscopically characterise, and study the reactivity of the putative intermediates in enzymatic processes. In the last 20 years, a number of precursor iron(II) complexes with their high-valent oxoiron(IV) intermediates have been prepared by the use of multidentate $\mathrm{N}$-donor ligands such as TPA, N4Py, Py5 [2,6-(bis-(bis-2-pyridyl)methoxymethane)pyridine] and TPEN $\left(\mathrm{N}, \mathrm{N}, \mathrm{N}^{\prime}, \mathrm{N}^{\prime}\right.$-tetrakis(2-pyridylmethyl)- ethylenediamine) [37-42]. These complexes as catalysts and/or intermediates catalyse all types of oxidation reactions such as epoxidations, heteroatom oxidations, and even C-H oxidations including hydrogen-atom transfer (HAT) and oxygen-atom transfer (OAT) [43-45].

The primary aspect of ligand selection, as a continuation of our previous work, was to increase the reactivity of the catalyst and its intermediates towards flavanone [46]. For this

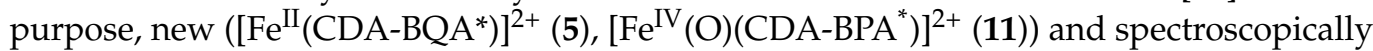
well-characterised $\left(\left[\mathrm{Fe}^{\mathrm{II}}\left(\mathrm{CDA}-\mathrm{BPA}^{*}\right)\right]^{2+}(6),\left[\mathrm{Fe}^{\mathrm{II}}(\mathrm{Bn}-\mathrm{TPEN})\left(\mathrm{CH}_{3} \mathrm{CN}\right)\right]^{2+}(3)\left[\mathrm{Fe}^{\mathrm{IV}}(\mathrm{O})(\mathrm{Bn}-\right.\right.$ TPEN) $\left.]^{2+}(9)\right)$ nonheme iron(II) and oxoiron(IV) complexes, were chosen. Since nonheme oxomanganese (IV) complexes have proven to be versatile oxidants [40], in addition to iron-containing models we also aimed to elucidate the role of the metal cofactor through the comparison of well-defined iron- and manganese-containing systems. Previously reported $\left[\mathrm{Mn}^{\mathrm{II}}\left(\mathrm{N} 4 \mathrm{Py}^{*}\right)\left(\mathrm{CH}_{3} \mathrm{CN}\right)\right]^{2+}(2),\left[\mathrm{Mn}^{\mathrm{II}}(\mathrm{Bn}-\mathrm{TPEN})\left(\mathrm{CH}_{3} \mathrm{CN}\right)\right]^{2+}(4)$ as catalysts and $\left[\mathrm{Mn}^{\mathrm{IV}}(\mathrm{O})\left(\mathrm{N}_{4} \mathrm{Py}^{*}\right)\right]^{2+}(\mathbf{8}),\left[\mathrm{Mn}^{\mathrm{IV}}(\mathrm{O})(\mathrm{Bn}-\mathrm{TPEN})\right]^{2+}(\mathbf{1 0})$ as possible intermediates in the oxidation reactions were chosen for these measurements $[39,40]$. In this work, catalytic oxidation of flavanone was performed with 2, 3, 4, 5, and 6 . Catalytic oxidation of ethylbenzene was performed with 5 and 6 , and stoichiometric oxidation reactions were performed with 7,8 , 9, 10, and 11. $N, N, N^{\prime}, N^{\prime}$-tetrakis(2-pyridylmethyl)ethylenediamine (TPEN) is a well-known metal chelator. TPEN complexes are often used as $\mathrm{Zn}(\mathrm{II})$ and $\mathrm{Cd}(\mathrm{II})$ indicators, and in this case, substituting the pyridine for quinoline results in enhancement of fluorescence intensity and use of these ligands as fluorescent probes $[47,48]$. Fe(II) complexes of the TPEN group of ligands have interesting electronical properties, where conformational changes 
are linked to different spin-state interconversion processes [41]. Due to the interesting redox behaviour of these Fe(II) complexes they have been studied as superoxide dismutase mimics [49] and for their reactivity towards hydrogen peroxide [50].

In this work, a single-crystal structure was obtained for the complex $\left[\mathrm{Fe}^{\mathrm{II}}( \pm \mathrm{CDA}\right.$ $\mathrm{BQA})]\left(\mathrm{CF}_{3} \mathrm{SO}_{3}\right)_{2}$ (5). The complex was prepared with the racemic version of ligand CDA$\mathrm{BQA}^{*}$. In the CSD database, there are 29 structures of $\mathrm{Fe}(\mathrm{II})$ complexes of these types of ligands, with four pyridyl or quinoline groups connected by an ethylenediamine or cyclohexanediamine linker [51,52]. The only reported Fe(II) complex with a cyclohexanediamine linker is $\left[\mathrm{Fe}^{\mathrm{II}}\left(\mathrm{CDA}-\mathrm{BPA}^{*}\right)\right]\left(\mathrm{ClO}_{4}\right)_{2}(\mathbf{6})(\mathrm{CSD}$ refcode YAMXAL) [41] The geometry of the newly synthesised $\left[\mathrm{Fe}^{\mathrm{II}}\left(\mathrm{CDA}-\mathrm{BQA}^{*}\right)\right]\left(\mathrm{CF}_{3} \mathrm{SO}_{3}\right)_{2}(5)$ (Figure 1 ) and $\left[\mathrm{Fe}^{\mathrm{II}}\left(\mathrm{CDA}-\mathrm{BPA}^{*}\right)\right]\left(\mathrm{ClO}_{4}\right)_{2}$ (6) is compared in Figure 2 and Table 1. Both complexes are prepared with racemic ligands, however, 5 crystallised as a racemate, while 6 has spontaneously resolved into its optical isomers, containing only the $(R, R)$ enantiomer. While complex 6 has a regular octahedral geometry, the $\mathrm{Fe}-\mathrm{N}$ bonds in $\mathbf{5}$ are elongated, forming a pentagonal bipyramidal geometry with an equatorial vacancy, as determined using the program FindGeo [53]. The reason for this is likely the steric crowding of the quinoline groups in $\mathbf{5}$. The significantly longer Fe-N bond lengths $(>2.2 \AA)$ are in agreement with a high spin Fe(II) centre in 5 . The UV-Vis spectrum of 5 in acetonitrile is dominated by the intense $\pi-\pi^{*}$ band at $307 \mathrm{~nm}$ $\left(=12,800 \mathrm{M}^{-1} \mathrm{~cm}^{-1}\right)$, and an additional broad feature of low intensity between 330 and $460 \mathrm{~nm}\left(\lambda_{\max }=356\right.$ with $\left.\varepsilon=2080 \mathrm{M}^{-1} \mathrm{~cm}^{-1}\right)$ can be assigned to an MLCT transition. The weak intensity is consistent with the high spin state of the iron(II) centre [46].

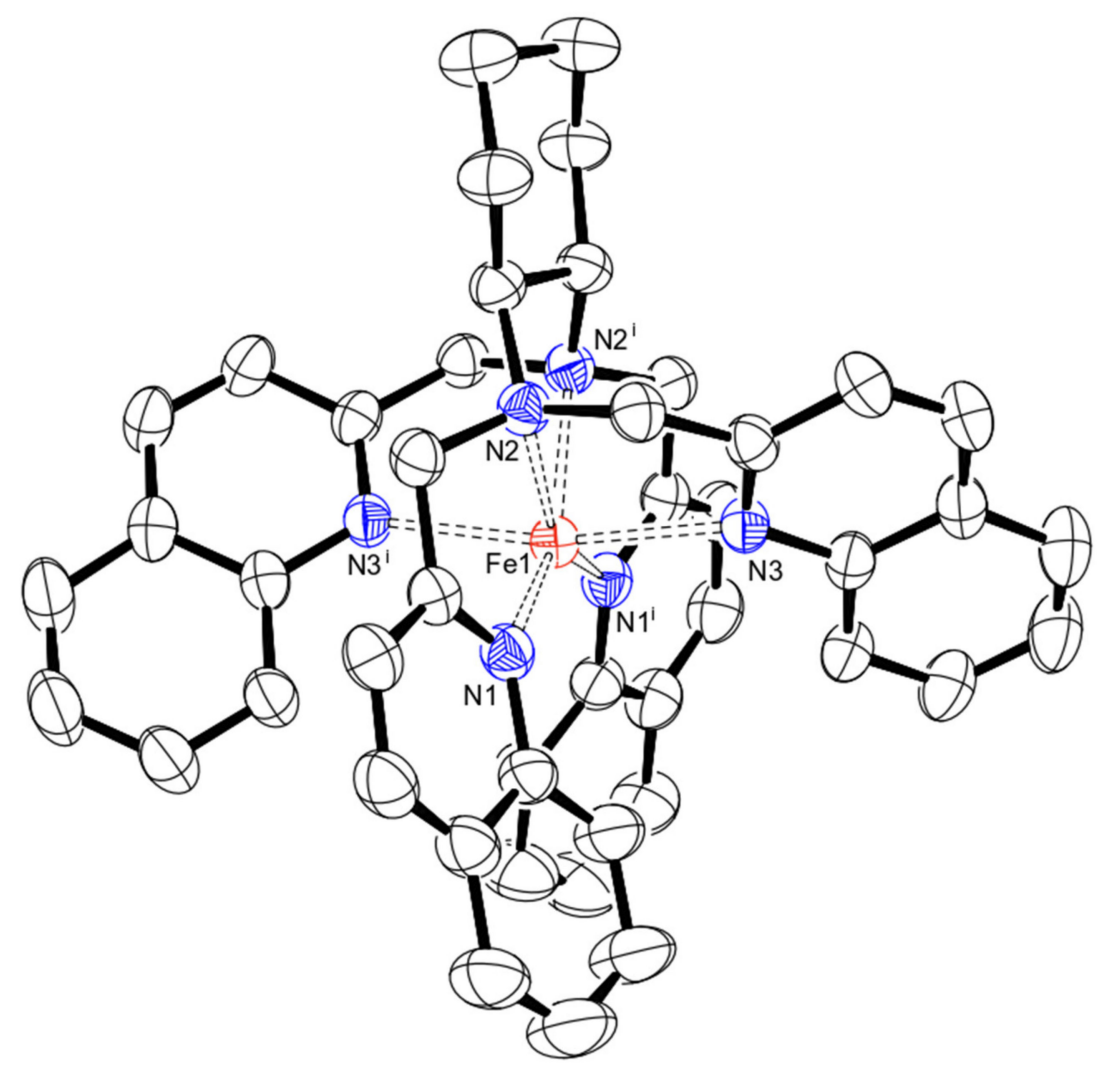

Figure 1. X-ray structure of $\left.\mathrm{Fe}^{\mathrm{II}}\left( \pm \mathrm{CDA}-\mathrm{BQA}^{*}\right)\right]\left(\mathrm{CF}_{3} \mathrm{SO}_{3}\right)_{2}$ (5), showing a 30\% probability of thermal ellipsoids. 

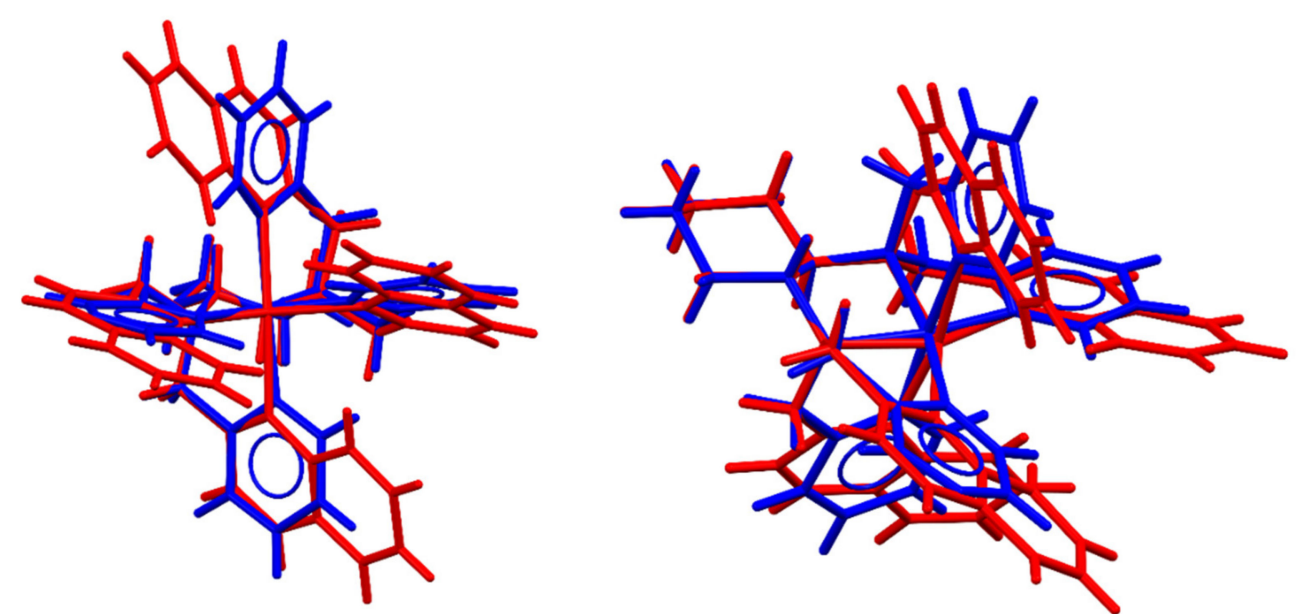

Figure 2. Overlay of structures $\left.\mathrm{Fe}^{\mathrm{II}}\left(\mathrm{CDA}-\mathrm{BQA}^{*}\right)\right]\left(\mathrm{CF}_{3} \mathrm{SO}_{3}\right)_{2}(5)$ (red) and $\left[\mathrm{Fe}^{\mathrm{II}}\left(\mathrm{CDA}-\mathrm{BPA}^{*}\right)\right]\left(\mathrm{ClO}_{4}\right)_{2}$ (6) (blue) containing only $(R, R)$-enantiomers of the ligands.

Table 1. Selected bond lengths of complex $\left[\mathrm{Fe}^{\mathrm{II}}\left( \pm \mathrm{CDA}-\mathrm{BQA}^{*}\right)\right]\left(\mathrm{CF}_{3} \mathrm{SO}_{3}\right)_{2}$ (5) compared to the literature example of $\left[\mathrm{Fe}^{\mathrm{II}}\left(\mathrm{CDA}-\mathrm{BPA}^{*}\right)\right]\left(\mathrm{ClO}_{4}\right)_{2}(6)$ complex. The geometry was determined using the program FindGeo [53].

\begin{tabular}{ccccc}
\hline & Fe-N1/A & Fe-N2/A & Fe-N3/Å & Geometry/RMSD/Å \\
\hline$\left[\mathrm{Fe}^{\mathrm{II}}\left( \pm \mathrm{CDA}-\mathrm{BQA}^{*}\right)\right]\left(\mathrm{CF}_{3} \mathrm{SO}_{3}\right)_{2}(\mathbf{5})$ & 2.194 & 2.238 & 2.252 & $\begin{array}{c}\text { Pentagonal bipyramid with a vacancy } \\
\text { (equatorial) (regular) } \\
0.271\end{array}$ \\
{$\left[\mathrm{Fe}^{\mathrm{II}}\left(\mathrm{CDA} \mathrm{BPA}^{*}\right)\right]\left(\mathrm{ClO}_{4}\right)_{2}(\mathbf{6})[41]$} & 1.993 & 2.012 & 1.994 & $\begin{array}{c}\text { Octahedron (regular) } \\
0.369\end{array}$ \\
\hline
\end{tabular}

\subsection{Catalytic Oxidation Reactions}

The catalytic activities of the three ferrous and two manganese complexes [Fe $\mathrm{Fe}^{\mathrm{II}}(\mathrm{Bn}-$

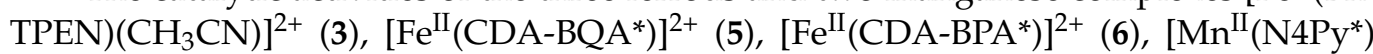
$\left.\left(\mathrm{CH}_{3} \mathrm{CN}\right)\right]^{2+}(2)$ and $\left[\mathrm{Mn}^{\mathrm{II}}(\mathrm{Bn}-\mathrm{TPEN})\left(\mathrm{CH}_{3} \mathrm{CN}\right)\right]^{2+}(4)$ were studied in the oxidation of flavanone, utilising mCPBA (meta-chloroperoxybenzoic acid) as the co-oxidant. The oxidation reactions were carried out under standard catalytic conditions (5:100:500 ratio for the catalyst:substrate:oxidant) in acetonitrile at room temperature (Table 2 and Figure 3). Similarly to our previous results, it took less than $10 \mathrm{~min}$ to have about $30-36 \%$ and $19-24 \%$ yields (based on the substrate) for the iron(II)- and manganese(II)-catalysed reactions, respectively. Much lower yields (0.36 and 2.8\%) were observed for the $\mathrm{Fe}\left(\mathrm{ClO}_{4}\right)_{2}$ and $\mathrm{Mn}\left(\mathrm{ClO}_{4}\right)_{2}$ salts, respectively. Both the iron(II) and manganese(II)-catalysed oxidations of flavanone produced flavones $(\mathrm{F})$ as a major product in all cases in addition to two minor products, namely 2-hydroxy-2-phenyl-chroman-4-one (A, 2-hydroxy-flavanone) and its open tautomeric form 1-(2-hydroxy-phenyl)-3-phenyl-propane-1,3-dione (D). It was found earlier [46] that complex 1 together with mCPBA oxidizes flavanone, and a turnover number (TON) of 6.93 for F, 0.11 for D and 0.02 for A was obtained with an overall yield of $9.42 \%$. Its manganese analogue produced an overall yield of $18.8 \%$, TON for $\mathrm{F}=3.58$, TON for $\mathrm{D}=0.19$ and $\mathrm{TON}$ for $\mathrm{A}=\sim 0.01$. 
Table 2. Catalytic oxidation of flavanone $\left(\mathrm{FH}_{2}\right)$ carried out by $2,3,4,5$ and 6 with $\mathrm{mCPBA}$ in $\mathrm{CH}_{3} \mathrm{CN}$ at $25^{\circ} \mathrm{C}$.

\begin{tabular}{|c|c|c|c|c|c|c|c|c|c|}
\hline $\mathbf{M}^{\mathrm{II}}$ & $\begin{array}{c}{\left[\mathrm{H}_{2} \mathrm{O}\right]} \\
/ \mathrm{mM}\end{array}$ & $\begin{array}{l}{\left[\mathrm{M}^{\mathrm{II}}\right]} \\
/ \mathrm{mM}\end{array}$ & $\begin{array}{l}{\left[\mathrm{FH}_{2}\right]} \\
/ \mathrm{mM}\end{array}$ & $\begin{array}{c}{[m \mathrm{CPBA}]} \\
/ \mathrm{mM}\end{array}$ & $\begin{array}{l}\text { Yield (F) } \\
\qquad / \% \\
\end{array}$ & TON & $\begin{array}{c}\text { Yield (D) }^{\mathrm{c}} \\
\quad / \% \\
\end{array}$ & TON & $\begin{array}{c}\text { Yield }_{\mathbf{t}} \\
\quad / \%\end{array}$ \\
\hline $\begin{array}{c}{\left[\mathrm{Fe}^{\mathrm{II}}\left(\mathrm{CDA}-\mathrm{BPA}^{*}\right)\right]^{2+}} \\
(\mathbf{6})\end{array}$ & 44 & 5 & 100 & 500 & 35.2 & 7.04 & 1.15 & 0.23 & 36.35 \\
\hline $\begin{array}{c}{\left[\mathrm{Fe}^{\mathrm{II}}(\mathrm{Bn}-\mathrm{TPEN})\right]^{2+}} \\
(3)\end{array}$ & 44 & 5 & 100 & 500 & 29 & 5.8 & 1.4 & 0.28 & 30.4 \\
\hline $\begin{array}{c}{\left[\mathrm{Fe}^{\mathrm{II}}\left(\mathrm{CDA}-\mathrm{BQA}^{*}\right)\right]^{2+}} \\
(5)\end{array}$ & 44 & 5 & 100 & 500 & 20.8 & 4.16 & 0.83 & 0.17 & 21.63 \\
\hline $\begin{array}{c}{\left[\mathrm{Mn}^{\mathrm{II}}\left(\mathrm{N}^{\prime} \mathrm{Py}^{*}\right)\right]^{2+}} \\
(2)\end{array}$ & 44 & 5 & 100 & 500 & 17.9 & 3.58 & 0.92 & 0.19 & 18.8 \\
\hline $\begin{array}{c}{\left[\mathrm{Mn}^{\mathrm{II}}\left(\mathrm{N} 4 \mathrm{Py}^{*}\right)\right]^{2+}} \\
(2)\end{array}$ & 55 & 5 & 100 & 500 & 15.7 & 3.14 & 1.2 & 0.23 & 16.9 \\
\hline $\begin{array}{c}{\left[\mathrm{Mn}^{\mathrm{II}}\left(\mathrm{N}^{\prime} \mathrm{Py}^{*}\right)\right]^{2+}} \\
(2)\end{array}$ & 65 & 5 & 100 & 500 & 13.8 & 2.76 & 1.45 & 0.3 & 15.25 \\
\hline $\begin{array}{c}{\left[\mathrm{Mn}^{\mathrm{II}}\left(\mathrm{N} 4 \mathrm{Py}^{*}\right)\right]^{2+}} \\
(2)\end{array}$ & 75 & 5 & 100 & 500 & 12.2 & 2.44 & 2.4 & 0.48 & 14.64 \\
\hline $\begin{array}{c}{\left[\mathrm{Mn}^{\mathrm{II}}\left(\mathrm{N} 4 \mathrm{Py}^{*}\right)\right]^{2+}} \\
(2)\end{array}$ & 85 & 5 & 100 & 500 & 10.7 & 2.14 & 3.2 & 0.64 & 13.9 \\
\hline $\begin{array}{c}{\left[\mathrm{Mn}^{\mathrm{II}}\left(\mathrm{N} 4 \mathrm{Py}^{*}\right)\right]^{2+}} \\
(2)\end{array}$ & 95 & 5 & 100 & 500 & 9 & 1.88 & 4.2 & 0.92 & 13.2 \\
\hline $\begin{array}{c}{\left[\mathrm{Mn}^{\mathrm{II}}\left(\mathrm{N} 4 \mathrm{Py}^{*}\right)\right]^{2+}} \\
(2)\end{array}$ & 44 & 5 & $100^{a}$ & 500 & $16.8^{\mathrm{a}}$ & 3.36 & 1.1 & 0.2 & 17.9 \\
\hline $\begin{array}{c}{\left[\mathrm{Mn}^{\mathrm{II}}\left(\mathrm{N} 4 \mathrm{Py}^{*}\right)\right]^{2+}} \\
(\mathbf{2})\end{array}$ & 44 & 5 & $100^{b}$ & 500 & $11.2^{b}$ & 2.24 & 1.8 & 0.36 & 12.95 \\
\hline $\begin{array}{c}{\left[\mathrm{Mn}^{\mathrm{II}}(\mathrm{Bn}-\mathrm{TPEN})\right]^{2+}} \\
(4)\end{array}$ & 44 & 5 & 100 & 500 & 23.1 & 4.62 & 0.61 & 0.12 & 23.7 \\
\hline
\end{tabular}

${ }^{a}$ In the presence of 2,6-di-tert-butylphenol (2,6-DTBP), [2,6-DTBP] $=25 \mathrm{mM} .{ }^{\mathrm{b}}$ In the presence of 2,6-di-tert-butylphenol (2,6-DTBP), $[2,6-\mathrm{DTBP}]=60 \mathrm{mM}^{\mathrm{c}}{ }^{\mathrm{c}}$ Yield of $\mathrm{A}$ is less than $0.1 \%$.
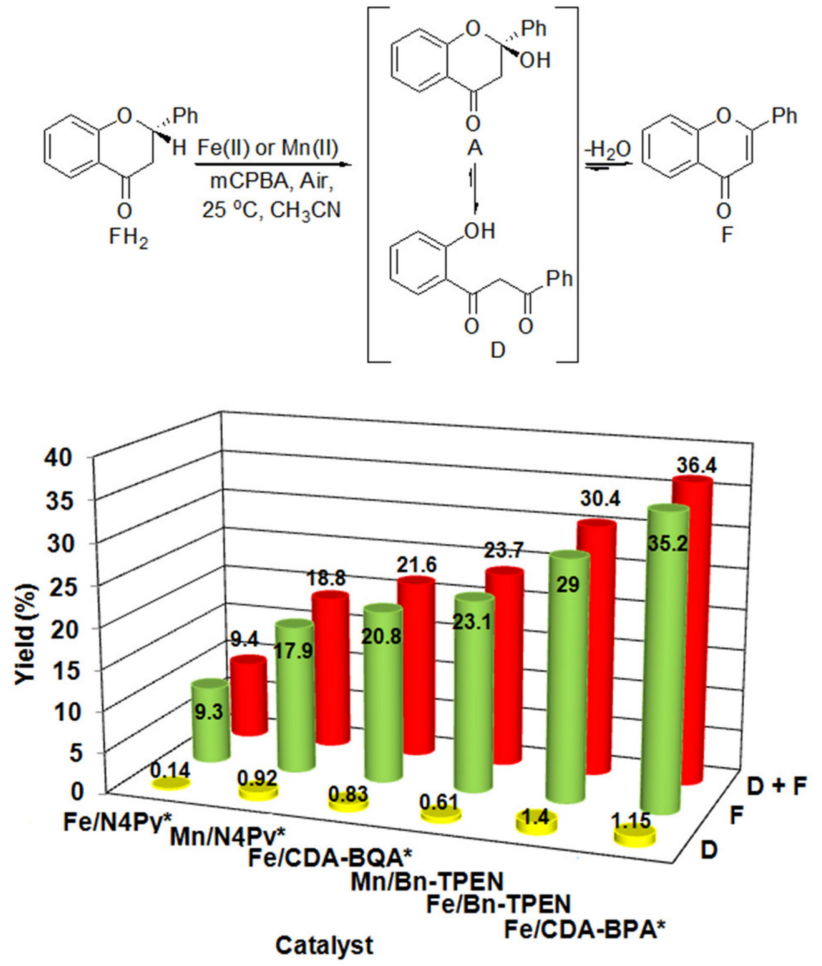

Figure 3. Comparison of the flavones-synthase activity of iron(II) and manganese(II) complexes. Conditions: $\left[\mathrm{M}^{\mathrm{II}}\right]=5 \mathrm{mM},\left[\mathrm{FH}_{2}\right]=100 \mathrm{mM}$ and $[m \mathrm{CPBA}]=500 \mathrm{mM}$ in $\mathrm{CH}_{3} \mathrm{CN}$ at $25^{\circ} \mathrm{C}$. 
It is important to mention that the amount of 1,3-dione (D) can be increased from $0.92 \%$ (TON $=0.19)$ to $4.2 \%(\mathrm{TON}=0.92)$ in the presence of $\mathrm{H}_{2} \mathrm{O}$, suggesting an equilibrium step during the flavone formation (Figure 4B). However, when 2,6-di-tert-butylphenol (DTBP) was added significantly less flavanone was converted, suggesting a free-radical type mechanism as a parallel process of the metal-based oxidation (Figure 4A). Significantly higher yields were observed for $3(30.4 \%$, TON for $\mathrm{F}=5.80$, TON for $\mathrm{D}=0.28), \mathbf{5}(21.6 \%$, TON for $\mathrm{F}=4.16$, TON for $\mathrm{D}=0.17), 6(36.35 \%$, TON for $\mathrm{F}=7.04$, TON for $\mathrm{D}=0.23)$ and 4 , suggesting clearly that the ligand framework and the nature of the metal influenced the catalytic activities of these complexes. The relative reactivities of iron(II) and manganese(II) complexes are in the order of $\left[\mathrm{Fe}^{\mathrm{II}}\left(\mathrm{CDA}-\mathrm{BPA}^{*}\right)\right]^{2+}(6)>\left[\mathrm{Fe}^{\mathrm{II}}(\mathrm{Bn}-\mathrm{TPEN})\left(\mathrm{CH}_{3} \mathrm{CN}\right)\right]^{2+}(3)$ $>\left[\mathrm{Mn}^{\mathrm{II}}(\mathrm{Bn}-\mathrm{TPEN})\left(\mathrm{CH}_{3} \mathrm{CN}\right)\right]^{2+}(4)>\left[\mathrm{Fe}^{\mathrm{II}}\left(\mathrm{CDA}-\mathrm{BQA}^{*}\right)\right]^{2+}(5)>\left[\mathrm{Mn}^{\mathrm{II}}\left(\mathrm{N}_{4} \mathrm{Py}^{*}\right)\left(\mathrm{CH}_{3} \mathrm{CN}\right)\right]^{2+}$ $(2)>\left[\mathrm{Fe}^{\mathrm{II}}\left(\mathrm{N} 4 \mathrm{Py}^{*}\right)\left(\mathrm{CH}_{3} \mathrm{CN}\right)\right]^{2+}(\mathbf{1})$. It should be underlined that the presence of both the theoretical tautomers (A and D) of the acid-labile intermediate of flavone strongly supports the hypothesis that flavone biosynthesis proceeds via 2-hydroxylation of flavanone. A similar mechanism was proposed for the cytochrome P450 monooxygenase (FS II) and other 2-oxoglutarate-dependent dioxygenases.
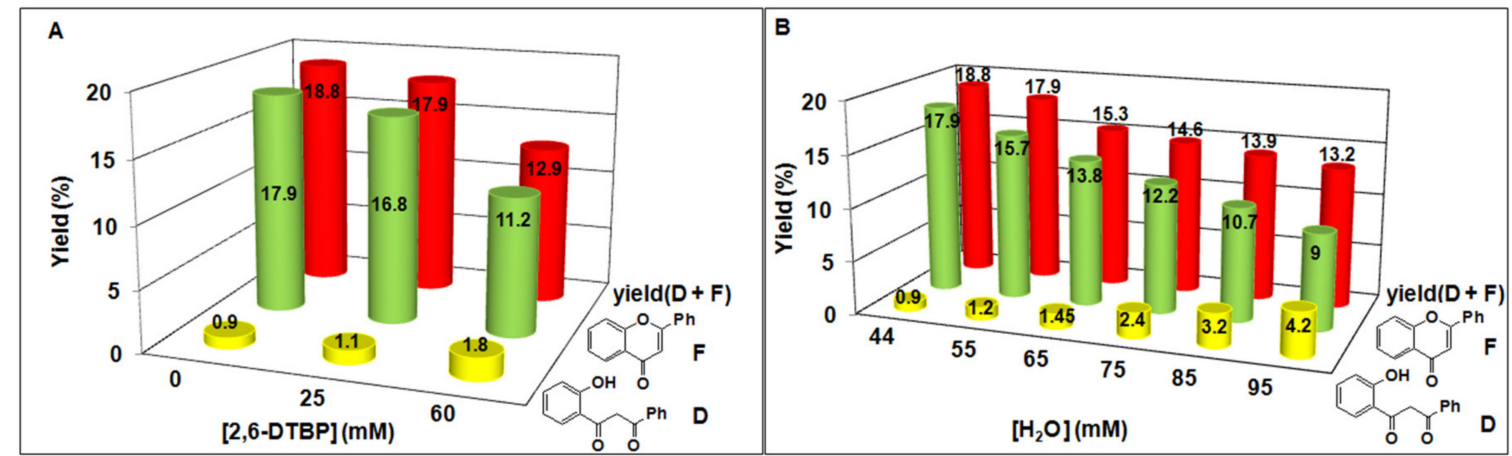

Figure 4. (A) Comparison of the product formation in the $\left[\mathrm{Mn}^{\mathrm{II}}\left(\mathrm{N} 4 \mathrm{Py}^{*}\right)\left(\mathrm{CH}_{3} \mathrm{CN}\right)\right]^{2+}$ (2) catalysed oxidation of flavanone with $\mathrm{mCPBA}$ as co-oxidant and 2,6-DTBP as a radical trapping agent. (B) Comparison of the product formation in the presence of added water.

Recently, chiral N4Py-type and L-proline derived aminopyridine containing oxoiron(IV) complexes were reported which could perform enantioselective oxidation of various substrates such as thioanisole, hydrocarbons, alkenes and substituted cyclohexanones [31,33]. To the best of our knowledge, these are the first examples of chiral nonheme oxoiron(IV) complexes tested in asymmetric C-H hydroxylation reactions. Since flavanone is a chiral molecule including benzylic $\mathrm{C}-\mathrm{H}$ bonds, oxidative kinetic resolution (OKR) of racemic flavanones can in principle also be performed with a chiral iron catalyst and oxoiron(IV) intermediates. The oxidation of ethylbenzene that can be used as a model compound of flavanone, by chiral $\left[\mathrm{Fe}^{\mathrm{IV}}(\mathrm{O})\left(\mathrm{N} 4 \mathrm{Py}^{*}\right)\right]^{2+}(7)$ species showed moderate enantioselectivities up to $33 \%$ ee as a result of a non-rebound mechanism including the epimerization of the long-lived alkyl radical before the rebound step [36]. To increase the enantioselectivity, we also examined the enantioselectivity of the $\left[\mathrm{Fe}^{\mathrm{II}}\left(\mathrm{CDA}-\mathrm{BPA}^{*}\right)\right]^{2+}(6)$ catalyst and the in situ generated $\left[\mathrm{Fe}^{\mathrm{IV}}(\mathrm{O})\left(\mathrm{CDA}-\mathrm{BPA}^{*}\right)\right]^{2+}(\mathbf{1 1})$ intermediate from 6 and $\mathrm{PhIO}$ in the asymmetric C-H hydroxylation of ethylbenzene utilizing TBHP and $\mathrm{PhIO}$ as co-oxidants (Figure 5 and Table 3). In these probe reactions, moderate enantioselective hydroxylation could be obtained in all cases, so the studies on oxidative kinetic resolution of racemic flavanones were discarded. 


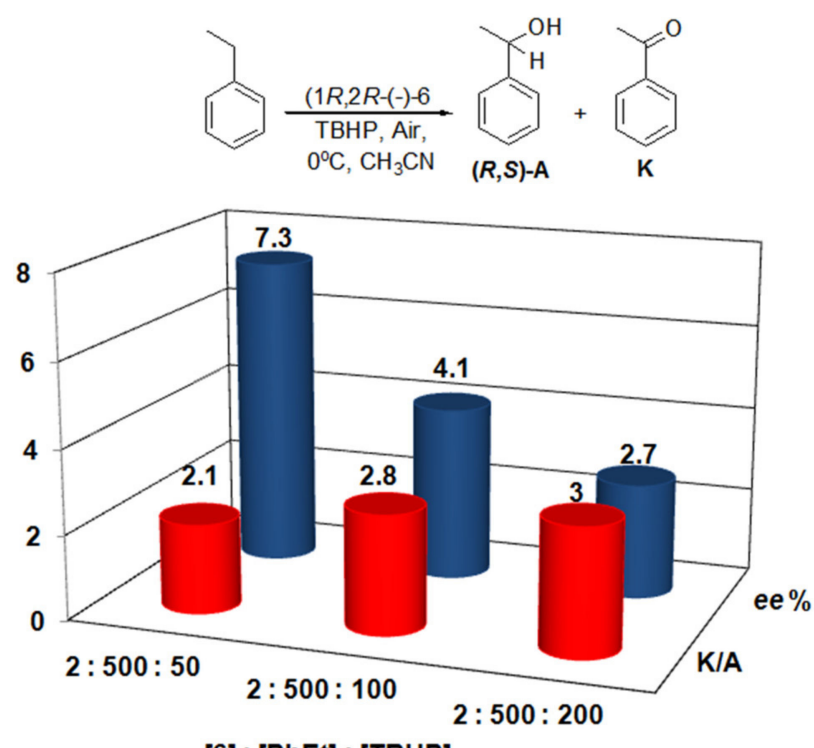

[6] : [PhEt] : [TBHP]

Figure 5. Dependence of the K/A ratio and the enantiomeric excess (ee\%) on the oxidant concen-

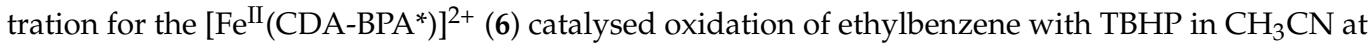
$0{ }^{\circ} \mathrm{C}$.

Table 3. Catalytic oxidation of ethylbenzene carried out by $(R, R)-(-)-6$ and $(R, R)-(-)-5$ with various co-oxidants ${ }^{\text {a }}$.

\begin{tabular}{|c|c|c|c|c|c|}
\hline [6]:[PhEt]:[Co-oxidant] & TON (A) ${ }^{b}$ & TON (K) ${ }^{c}$ & $\begin{array}{l}\text { Yield } \\
/ \% \mathrm{~d}\end{array}$ & $\mathrm{~K} / \mathrm{A}$ & $\begin{array}{l}e e \\
l \%\end{array}$ \\
\hline 2:500:50 (ТВHP) & 1.38 & 2.83 & 16.84 & 2.05 & $7.25(\mathrm{R})$ \\
\hline 2:500:100 (ТВHР) & 1.82 & 5.20 & 14.04 & 2.86 & $4.13(\mathrm{R})$ \\
\hline 2:500:200 (ТВHP) & 2.06 & 6.17 & 8.23 & 3.00 & $2.68(\mathrm{R})$ \\
\hline 2:1500:16 (PhIO) & 0.96 & 2.14 & 38.75 & 2.23 & $12.21(\mathrm{R})$ \\
\hline [5]:[PhEt]:[Co-oxidant] & $\operatorname{TON}\left(\mathrm{A}^{\mathrm{b}}\right)$ & $\mathrm{TON}\left(\mathrm{K}^{\mathrm{c}}\right)$ & $\begin{array}{l}\text { Yield } \\
/ \% \mathrm{~d}\end{array}$ & $\mathrm{~K} / \mathrm{A}$ & $\begin{array}{l}e e \\
1 \%\end{array}$ \\
\hline 2:500:100 (ТВHР) & - & 10.08 & 20.16 & - & - \\
\hline
\end{tabular}

a Reaction conditions: see Experimental section. ${ }^{\mathrm{b}}$ 1-Phenylethanol. ${ }^{\mathrm{c}}$ Acetophenone. ${ }^{\mathrm{d}}$ Based on oxidant.

\subsection{Stoichiometric Oxidation Reactions}

We have previously reported for a family of aminopyridine containing oxoiron(IV) complexes, $\mathrm{Fe}^{\mathrm{IV}}(\mathrm{O})(\mathrm{N} 4 \mathrm{Py})$ [N4Py = N,N'-bis(2-pyridylmethyl)-N-bis(2-pyridyl)methylamine], $\mathrm{Fe}^{\mathrm{IV}}(\mathrm{O})(\mathrm{TPA})[\mathrm{TPA}=$ tris(2-pyridylmethyl)amine] that the reactivity in HAT and OAT reactions can be significantly enhanced by the introduction of 6-substituents on the pyridine rings (TPA), or by the replacement of one or more pyridyl arms of TPA, N4Py or N4Py* with quinolyl arms, despite their thermal stabilities [46,54,55]. Modification of the N4Py ligand as described above resulted in the following reaction rate orders for the flavanone oxidation: $\left[\mathrm{Fe}^{\mathrm{IV}}(\mathrm{O})\left(\mathrm{N} 2 \mathrm{Py}_{2} \mathrm{Q}^{*}\right)\right]^{2+}>\left[\mathrm{Fe}^{\mathrm{IV}}(\mathrm{O})(\mathrm{N} 4 \mathrm{Py})\right]^{2+}>\left[\mathrm{Fe}^{\mathrm{IV}}(\mathrm{O})\left(\mathrm{N} \mathrm{Py}^{*}\right)\right]^{2+}($ Table 4$)$, where the most reactive complex reacts 80 -fold faster than the slowest one [46]. The stability and reactivity of the complexes are also greatly influenced by the number of nitrogen-donor atoms and their hybrid state. For example the oxidation of ethylbenzene by pentadentate $\left[\mathrm{Fe}^{\mathrm{IV}}(\mathrm{O})(\mathrm{Bn}-\mathrm{TPEN})\right]^{2+}(9)$ complex with two $\mathrm{N}\left(\mathrm{sp}^{3}\right)$ and $3 \mathrm{~N}\left(\mathrm{sp}^{2}\right)$ donor atoms react 20-fold faster than that of $\left[\mathrm{Fe}^{\mathrm{IV}}(\mathrm{O})(\mathrm{N} 4 \mathrm{Py})\right]^{2+}$ [37]. Taking these results into account, further studies were performed using the previously published $\left[\mathrm{Fe}^{\mathrm{IV}}(\mathrm{O})(\mathrm{Bn}-\mathrm{TPEN})\right]^{2+}(9)$ and the newly synthetised $\left.\mathrm{Fe}^{\mathrm{IV}}(\mathrm{O})(\mathrm{CDA}-\mathrm{BPA})\right]^{2+}$ (11) complexes for the stoichiometric oxidation of flavanone. Complexes $\mathbf{9}$ and $\mathbf{1 1}$ could be generated from their iron(II) precursor complexes by literature methods using 2 equiv solid PhIO for 30-40 min [37,38]. The reaction of 6 with 
$\mathrm{PhIO}$ in acetonitrile at room temperature results in a green species (11), characterised by a characteristic absorption band at $740 \mathrm{~nm}\left(\varepsilon \approx 450 \mathrm{M}^{-1} \mathrm{~cm}^{-1}\right)$, which can be assigned as a ligand-field (d-d) transition on the low-spin ( $\mathrm{S}=1) \mathrm{Fe}(\mathrm{IV})$ centre. This species is much less stable $\left(\mathrm{t}_{1 / 2} \approx 2 \mathrm{~h}\right.$ at $\left.25^{\circ} \mathrm{C}\right)$ than that was found for $9\left(\mathrm{t}_{1 / 2} \approx 6 \mathrm{~h}\right.$ at $\left.25^{\circ} \mathrm{C}\right)$. Their decay can be significantly enhanced by the addition of flavanone.

Table 4. Rate constants and activation parameters for the oxidation of flavanone with oxometal(IV) complexes.

\begin{tabular}{|c|c|c|c|c|c|c|}
\hline Complex & $\begin{array}{c}10^{3} k_{2} \\
/ \mathrm{s}^{-1} \mathbf{M}^{-1}\end{array}$ & 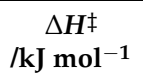 & $\begin{array}{c}\Delta S^{\ddagger} \\
/ \mathrm{J} \mathbf{m o l}^{-1} \mathbf{K}^{-1}\end{array}$ & $\begin{array}{c}\Delta G^{\ddagger} \\
/ \mathrm{kJ} \mathrm{mol}^{-1}\end{array}$ & $\begin{array}{l}\text { Solvent } \\
\text { /T }\end{array}$ & Refs. \\
\hline$\left[\mathrm{Fe}^{\mathrm{IV}}(\mathrm{O})\left(\mathrm{N} 4 \mathrm{Py}^{*}\right)\right]^{2+}(7)$ & $0.24 \pm 0.01$ & $70 \pm 3$ & $-75 \pm 9$ & 92.2 & $\mathrm{CH}_{3} \mathrm{CN}\left(25^{\circ} \mathrm{C}\right)$ & [46] \\
\hline$\left[\mathrm{Fe}^{\mathrm{IV}}(\mathrm{O})(\mathrm{N} 4 \mathrm{Py})\right]^{2+}$ & $0.57 \pm 0.03$ & $63 \pm 4$ & $-93 \pm 13$ & 90.9 & $\mathrm{CH}_{3} \mathrm{CN}\left(25^{\circ} \mathrm{C}\right)$ & {$[46]$} \\
\hline$\left[\mathrm{Fe}^{\mathrm{IV}}(\mathrm{O})\left(\mathrm{N} 2 \mathrm{Py} 2 \mathrm{Q}^{*}\right)\right]^{2+}$ & $19.2 \pm 1.1$ & $48 \pm 2$ & $-121 \pm 8$ & 83.7 & $\mathrm{CH}_{3} \mathrm{CN}\left(25^{\circ} \mathrm{C}\right)$ & {$[46]$} \\
\hline$\left[\mathrm{Fe}^{\mathrm{IV}}(\mathrm{O})\left(\mathrm{N} 2 \mathrm{Py} 2 \mathrm{Q}^{*}\right)\right]^{2+}$ & $6.50 \pm 0.32$ & & & & $\mathrm{CH}_{3} \mathrm{CN}\left(10^{\circ} \mathrm{C}\right)$ & {$[46]$} \\
\hline$\left[\mathrm{Fe}^{\mathrm{IV}}(\mathrm{O})(\mathrm{Bn}-\mathrm{TPEN})\right]^{2+}(9)$ & $1340 \pm 67$ & $28 \pm 2$ & $-150 \pm 8$ & 72.7 & $\mathrm{CH}_{3} \mathrm{CN}\left(25^{\circ} \mathrm{C}\right)$ & This work \\
\hline$\left[\mathrm{Fe}^{\mathrm{IV}}(\mathrm{O})(\mathrm{Bn}-\mathrm{TPEN})\right]^{2+}(9)$ & $680 \pm 27$ & & & & $\mathrm{CH}_{3} \mathrm{CN}\left(10^{\circ} \mathrm{C}\right)$ & This work \\
\hline$\left[\mathrm{Fe}^{\mathrm{IV}}(\mathrm{O})(\mathrm{Bn}-\mathrm{TPEN})\right]^{2+}(9)$ & $1520 \pm 90$ & & & & $\mathrm{CH}_{3} \mathrm{CN} / \mathrm{TFE}\left(10^{\circ} \mathrm{C}\right)$ & This work \\
\hline$\left[\mathrm{Fe}^{\mathrm{IV}}(\mathrm{O})\left(\mathrm{CDA}-\mathrm{BPA}^{*}\right)\right]^{2+}(\mathbf{1 1})$ & $970 \pm 40$ & & & & $\mathrm{CH}_{3} \mathrm{CN}\left(10^{\circ} \mathrm{C}\right)$ & This work \\
\hline$\left[\mathrm{Mn}^{\mathrm{IV}}(\mathrm{O})\left(\mathrm{N} 4 \mathrm{Py}^{*}\right)\right]^{2+}(\mathbf{8})$ & $0.58 \pm 0.03$ & & & & $\mathrm{CH}_{3} \mathrm{CN} / \mathrm{TFE}\left(25^{\circ} \mathrm{C}\right)$ & This work \\
\hline$\left[\mathrm{Mn}^{\mathrm{IV}}(\mathrm{O})(\mathrm{Bn}-\mathrm{TPEN})\right]^{2+}(\mathbf{1 0})$ & $420 \pm 15$ & $43 \pm 3$ & $-114 \pm 10$ & 76.7 & $\mathrm{CH}_{3} \mathrm{CN} / \mathrm{TFE}\left(10^{\circ} \mathrm{C}\right)$ & This work \\
\hline
\end{tabular}

The detailed kinetic measurements were carried out in $\mathrm{CH}_{3} \mathrm{CN}$ and $\mathrm{CH}_{3} \mathrm{CN} / \mathrm{CF}_{3} \mathrm{CH}_{2} \mathrm{OH}$ $(\mathrm{TFE})=1: 1$ solutions at $10-25^{\circ} \mathrm{C}$, and the decay of the oxoiron(IV) species $\mathbf{9}$ and $\mathbf{1 1}$ during the flavanone oxidation was followed as a decrease in absorbance at $\sim 740 \mathrm{~nm}$ (Figure 6 and Tables S2-S5). The yields of flavone were around $\sim 80 \%$ for both complexes. The reaction rates in the presence of 10-50 times excess of substrate obeyed pseudo-first-order kinetics, and the pseudo-first-order rate constants $\left(\mathrm{k}_{\mathrm{obs}}\right)$ were directly proportional to the concentration of flavanone, from which the reaction rate constants $\left(\mathrm{k}_{2}\right)$ are $0.68 \pm 0.027 \mathrm{M}^{-1} \mathrm{~s}^{-1}$ and $0.97 \pm 0.04 \mathrm{M}^{-1} \mathrm{~s}^{-1}$ for 9 and $\mathbf{1 1}$ at $10^{\circ} \mathrm{C}$, respectively (Figure 7 and Table 4). These values are three orders of magnitude higher than those observed for the previously published $\left[\mathrm{Fe}^{\mathrm{IV}}(\mathrm{O})\left(\mathrm{N} 2 \mathrm{Py} 2 \mathrm{Q}^{*}\right)\right]^{2+}$ species [46], showing clearly that the ligand framework significantly influenced the reactivity of the oxoiron(IV) species.
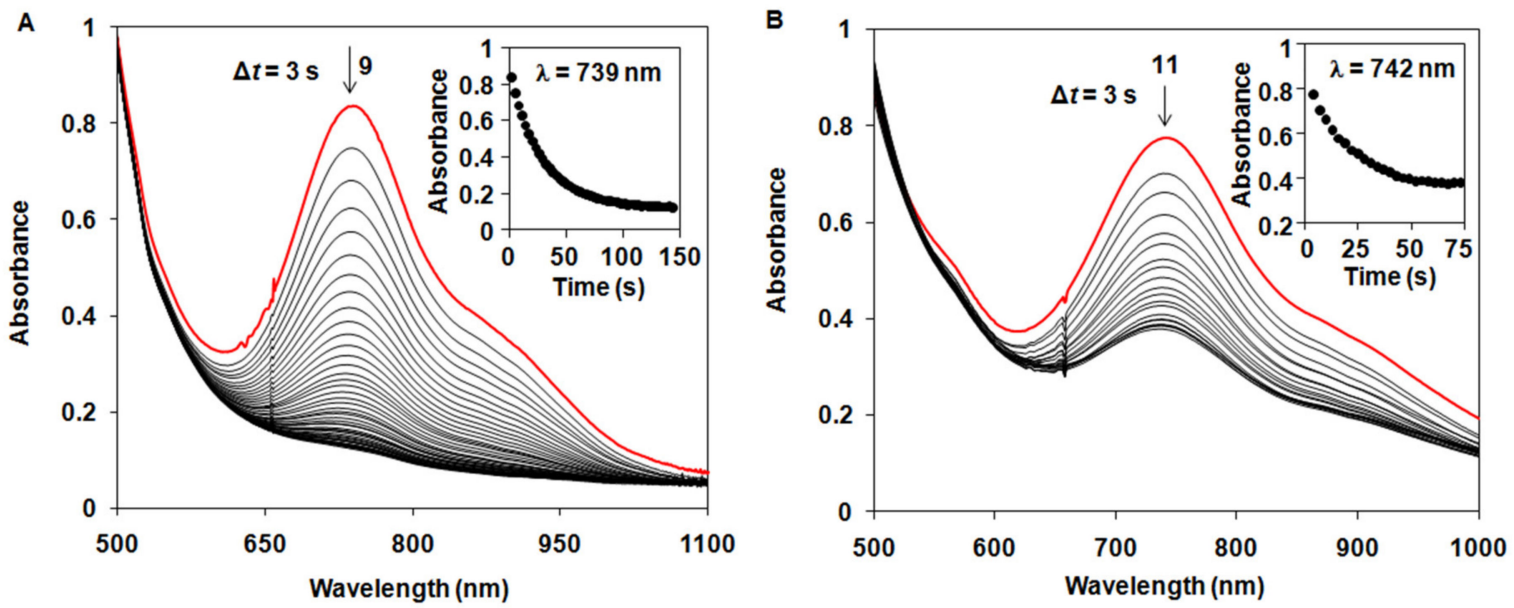

Figure 6. (A) UV-Vis spectral changes of $9\left(2 \mathrm{mM}\right.$, red line) upon addition of flavanone $(50 \mathrm{mM})$ in $\mathrm{CH}_{3} \mathrm{CN}$ at $10{ }^{\circ} \mathrm{C}$. The inset shows the time course of the decay of $\mathbf{9}$ monitored at $739 \mathrm{~nm}$. (B) UV-Vis spectral changes of $\mathbf{1 1}$ (2 mM, red line) upon addition of flavanone $(50 \mathrm{mM})$ in $\mathrm{CH}_{3} \mathrm{CN}$ at $10^{\circ} \mathrm{C}$. The inset shows the time course of the decay of $\mathbf{1 1}$ monitored at $742 \mathrm{~nm}$. 

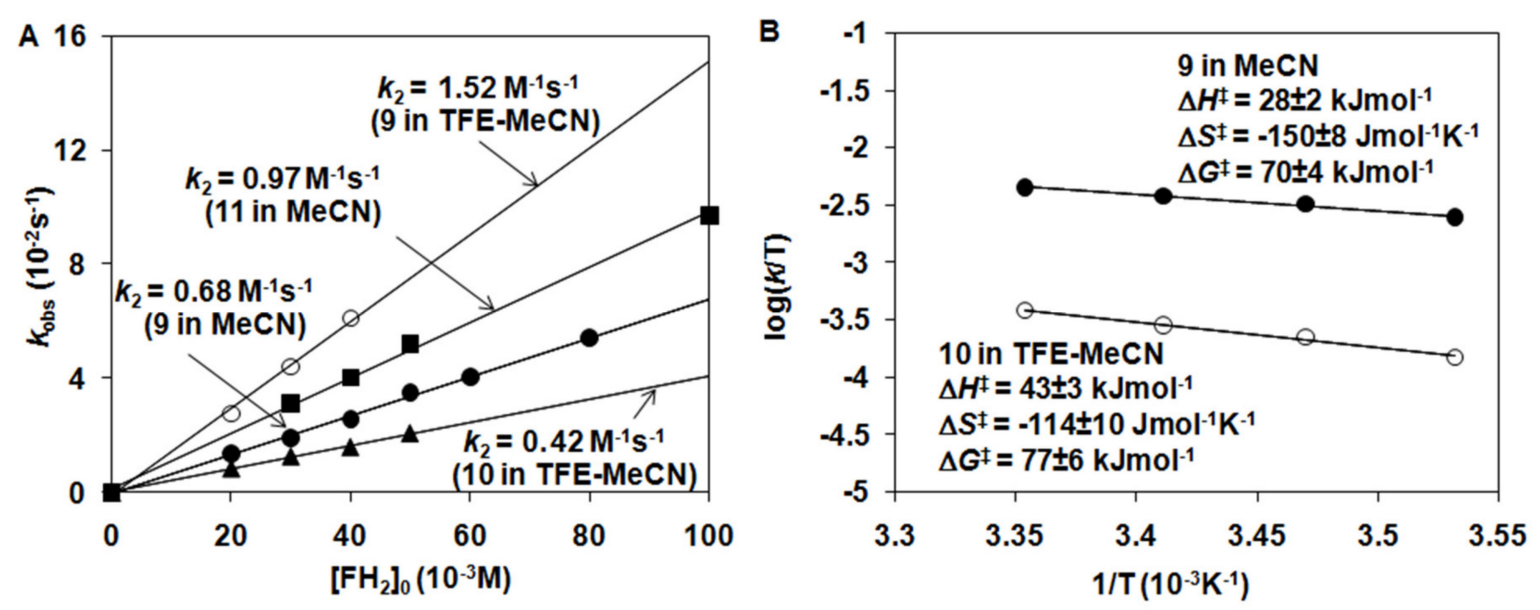

Figure 7. (A) Determination and comparison of second-order rate constants by plotting $\mathrm{k}_{\mathrm{obs}}$ values against flavanone concentration for a series of $\mathrm{M}^{\mathrm{IV}}(\mathrm{O})$ complexes in $\mathrm{CH}_{3} \mathrm{CN}$ at $10^{\circ} \mathrm{C},[\mathrm{M}]_{0}=2 \mathrm{mM}$. (B) Eyring plots of log $\mathrm{k} / \mathrm{T}$ versus $1 / \mathrm{T}$ for 9 and 10, $[9,10]=2 \mathrm{mM},\left[\mathrm{FH}_{2}\right]=50 \mathrm{mM}$.

The relative reactivity of oxoiron(IV) complexes is in the order of $\left[\mathrm{Fe}^{\mathrm{IV}}(\mathrm{O})(\mathrm{CDA}\right.$ $\left.\left.\mathrm{BPA}^{*}\right)\right]^{2+}(\mathbf{1 1})>\left[\mathrm{Fe}^{\mathrm{IV}}(\mathrm{O})(\mathrm{Bn}-\mathrm{TPEN})\right]^{2+}(\mathbf{9})>\left[\mathrm{Fe}^{\mathrm{IV}}(\mathrm{O})\left(\mathrm{N} 2 \mathrm{Py} 2 \mathrm{Q}^{*}\right)\right]^{2+}>\left[\mathrm{Fe}^{\mathrm{IV}}(\mathrm{O})(\mathrm{N} 4 \mathrm{Py})\right]^{2+}>$ $\left[\mathrm{Fe}^{\mathrm{IV}}(\mathrm{O})\left(\mathrm{N} \mathrm{Py}^{*}\right)\right]^{2+}(7)$, which is consistent with our catalytic results. Based on the temperature dependence of the reactivity of 9 (with $\Delta H^{\ddagger}=28 \pm 2 \mathrm{~kJ} \mathrm{~mol}^{-1}, \Delta S^{\ddagger}=-150 \pm 8 \mathrm{~J} \mathrm{~mol}^{-1}$ $\mathrm{K}^{-1}, \Delta G^{\ddagger}=72.7 \mathrm{~kJ} \mathrm{~mol}^{-1}$ ), the value of $-\mathrm{T} \Delta S^{\ddagger}$ determined was bigger than $\Delta H^{\ddagger}$, indicating an entropy-controlled reaction, contrary to the previously reported enthalpy-controlled reactions with N4Py-type ligands. As a result of a compensation effect increasing activation, enthalpies are offset by increasingly positive entropies yielding $\Delta H^{\ddagger}=114 \mathrm{~kJ} \mathrm{~mol}^{-1}$ at the intercept (Figure 8A). The experimentally determined difference between $\Delta G^{\ddagger}$ values is $20 \mathrm{~kJ} \mathrm{~mol}^{-1}$, which is significant and consistent with the observed reaction rate order (Figure 8B).
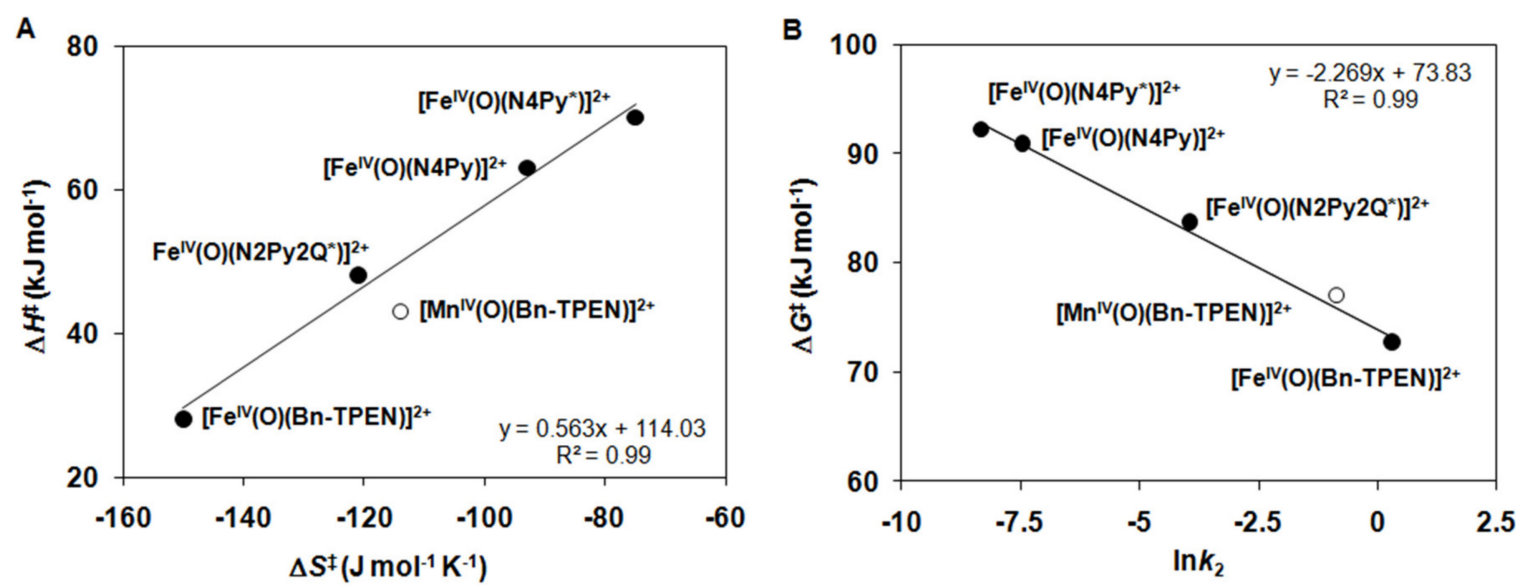

Figure 8. (A) Isokinetic plot and (B) plot of $\Delta G^{\ddagger}$ versus $\operatorname{lnk}_{2}$ for the oxidation of flavanone with various oxomanganese(IV) and oxoiron(IV) complexes.

To elucidate the role of the metal cofactor, such manganese and iron containing systems have been chosen from the literature where the structure of the high valent metal oxo intermediates are already known. Our choice fell on the $\left[\mathrm{Mn}^{\mathrm{IV}}(\mathrm{O})\left(\mathrm{N} 4 \mathrm{Py}^{*}\right)\right]^{2+}(8)$ and $\left[\mathrm{Mn}^{\mathrm{IV}}(\mathrm{O})(\mathrm{Bn}-\mathrm{TPEN})\right]^{2+}(\mathbf{1 0})$ complexes. These intermediates can be generated in TFE and TFE $/ \mathrm{CH}_{3} \mathrm{CN}$ by the use of PhIO as an oxidant, and the oxidation of flavanone can be investigated following their decrease in absorbances at $944 \mathrm{~nm}$ (8) and $1040 \mathrm{~nm}$ (10), respectively (Figure 9A). 

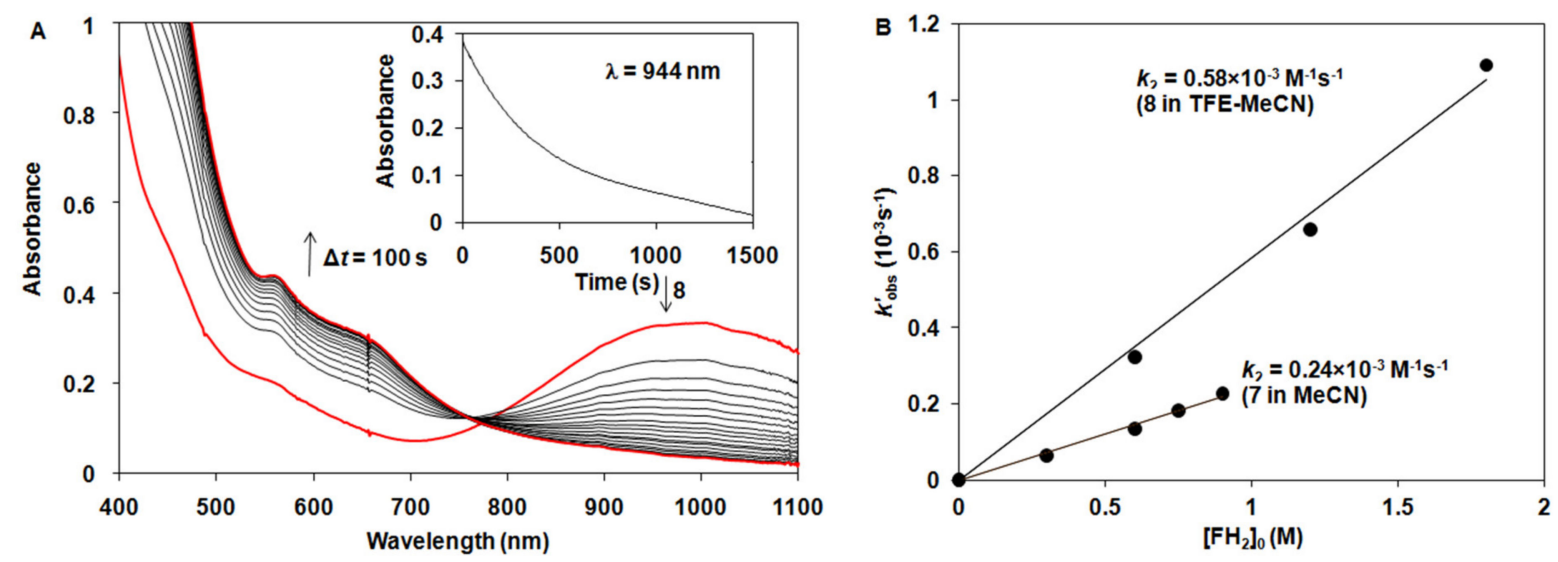

Figure 9. (A) UV-Vis spectral changes of 8 ( $2 \mathrm{mM}$, red line) upon addition of flavanone $(1.8 \mathrm{M})$ in $\mathrm{CH}_{3} \mathrm{CN} / \mathrm{TFE}$ at $25^{\circ} \mathrm{C}$. The inset shows the time nd course of the decay of 8 monitored at $944 \mathrm{~nm}$. (B) Determination and comparison of second-order rate constants by plotting $\mathrm{k}_{\mathrm{obs}}$ values against flavanone concentration for complexes 7 and 8 in $\mathrm{CH}_{3} \mathrm{CN}$ and $\mathrm{CH}{ }_{3} \mathrm{CN} / \mathrm{TFE}$ at $25^{\circ} \mathrm{C},[\mathrm{M}]_{0}=2 \mathrm{mM}$.

Due to the correct comparison of the iron and manganese-containing system, we first investigated the effect of the solvent on the reaction rate. The reaction of $\left[\mathrm{Fe}^{\mathrm{IV}}(\mathrm{O})(\mathrm{Bn}-\right.$ TPEN) $]^{2+}$ (9) with flavanone in $\mathrm{CH}_{3} \mathrm{CN} / \mathrm{TFE}$ (1:1) resulted in a 2-fold increase in rate, which is not considered significant. Considering the solvent effect, almost the same reaction rate was observed for the $\left[\mathrm{Fe}^{\mathrm{IV}}(\mathrm{O})\left(\mathrm{N}_{4} \mathrm{Py}^{*}\right)\right]^{2+}(7)$ and $\left[\mathrm{Mn}^{\mathrm{IV}}(\mathrm{O})\left(\mathrm{N}_{\mathrm{Py}}\right)^{*}\right]^{2+}(8)$ complexes with $\mathrm{k}_{2}=0.24(1) \times 10^{-3} \mathrm{M}^{-1} \mathrm{~s}^{-1}$ and $\mathrm{k}_{2}=0.58(3) \times 10^{-3} \mathrm{M}^{-1} \mathrm{~s}^{-1}$ at $25{ }^{\circ} \mathrm{C}$, respectively (Figure 9B). Comparing the reactions of $\left[\mathrm{Fe}^{\mathrm{IV}}(\mathrm{O})(\mathrm{Bn}-\mathrm{TPEN})\right]^{2+}(9)$ and $\left[\mathrm{Mn}^{\mathrm{IV}}(\mathrm{O})(\mathrm{Bn}-\right.$ TPEN) $]^{2+}(\mathbf{1 0})$ under the same conditions, a 3.5-fold difference in reaction rate was observed in favour of iron (Table 4 and Figure 7)). The difference in reaction rates and yields of products ( $\sim 80 \%$ flavone for $\mathbf{9}$ and $\sim 40 \%$ flavone for $\mathbf{1 0}$ based on the complex concentration) can be explained by a different mechanism based on the literature data. While in the case of oxoiron(IV) complexes the reactions occur mostly via an oxygen-rebound mechanism [56], in the case of manganese the process involving $\mathrm{C}-\mathrm{H}$ activation can be described mainly by a non-rebound mechanism with a smaller reaction rate (Scheme 3) [40].

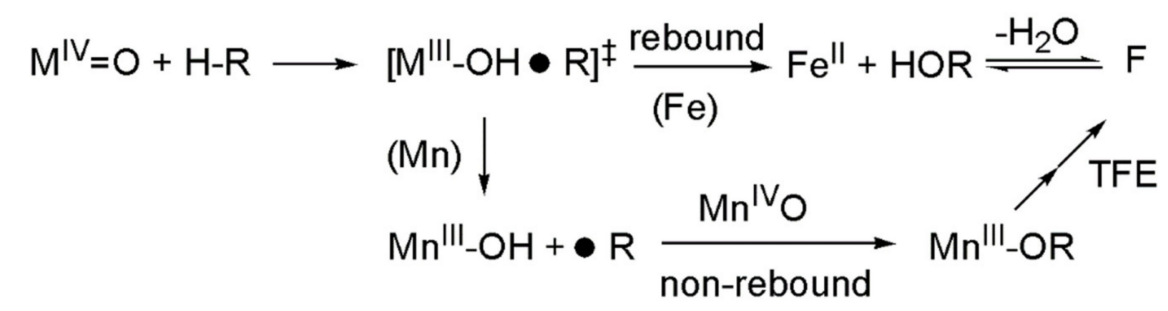

Scheme 3. Proposed mechanism for the C-H activation by oxoiron and oxomanganese complexes.

\section{Materials and Methods}

Reactions were carried out in ordinary glassware and chemicals were used as purchased from commercial suppliers without further purification. GC analyses were performed on an Agilent 6850 gas chromatograph equipped with a flame ionization detector and a $30 \mathrm{~m}$ SUPELCO BETA DEX225 (CHIRASIL-L-VAL) (Sigma-Aldrich, Budapest, Hungary) column. ESI-MS samples were analysed using a triple quadruple Micromass Quattro spectrometer (Waters, Milford, MA, USA) and an HPLC-MS system (Agilent Technologies 1200, Budapest, Hungary) coupled with a 6410 Triple-Quadrupole mass spectrometer, operating in a positive ESI mode. Synthesis of the ligand was carried out in a microwave reactor (CEM Discover), (CEM Inc, Scottsdale, AZ, USA) monitored by TLC on aluminium oxide $60 \mathrm{~F}_{254}$ neutral plates and detected with a UV lamp (254 nm). NMR spectra were 
obtained on a Bruker Avance 300 (Bruker Biospin AG, Fällanden, Switzerland) or 600 spectrometers, operating at 300 or $600 \mathrm{MHz}$ for ${ }^{1} \mathrm{H}$ and 75 or $150 \mathrm{MHz}$ for ${ }^{13} \mathrm{C}$. The spectra are recorded at room temperature. Chemical shifts, $\delta(\mathrm{ppm})$, indicate a downfield shift from the residual solvent signal $\left(\delta_{H}: 1.94 \mathrm{ppm}, \delta_{\mathrm{C}}: 118.26 \mathrm{ppm}\right.$ for $\mathrm{CD}_{3} \mathrm{CN}$ and $\delta_{H}: 7.26 \mathrm{ppm}, \delta_{C}$ : $77.16 \mathrm{ppm}$ for $\mathrm{CDCl}_{3}$ ). Coupling constants, $J$, are given in $\mathrm{Hz}$. The syntheses of most of the complexes used in this study have been previously reported: these complexes and the corresponding references are listed as follows: $\left[\mathrm{Fe}^{\mathrm{II}}(\mathrm{Bn}-\mathrm{TPEN})\left(\mathrm{CH}_{3} \mathrm{CN}\right)\right]^{2+}(3),\left[\mathrm{Fe}^{\mathrm{IV}}(\mathrm{O})(\mathrm{Bn}-\right.$ TPEN) $]^{2+}$ (9) [37,38], $\left[\mathrm{Mn}^{\mathrm{II}}(\mathrm{Bn}-\mathrm{TPEN})\left(\mathrm{CH}_{3} \mathrm{CN}\right)\right]^{2+}(\mathbf{4}),\left[\mathrm{Mn}^{\mathrm{IV}}(\mathrm{O})(\mathrm{Bn}-\mathrm{TPEN})\right]^{2+}$ (10) [40], $\left[\mathrm{Mn}^{\mathrm{II}}\left(\mathrm{N} 4 \mathrm{Py}^{*}\right)\left(\mathrm{CH}_{3} \mathrm{CN}\right)\right]^{2+}(\mathbf{2}),\left[\mathrm{Mn}^{\mathrm{IV}}(\mathrm{O})\left(\mathrm{N}_{\mathrm{PPy}}^{*}\right)\right]^{2+}(\mathbf{8})[39],\left[\mathrm{Fe}^{\mathrm{II}}\left(\mathrm{CDA}-\mathrm{BPA}^{*}\right)\right]^{2+}(\mathbf{6})$ [41].

Synthesis of ligands CDA-BPA* and CDA-BQA*. The synthesis was performed according to a modified previously reported procedure [47]. The amine (1 eq.), $\mathrm{K}_{2} \mathrm{CO}_{3}$ (12 eq.), 2-(chloromethyl)pyridine hydrochloride or 2-(chloromethyl)quinoline hydrochloride (4 eq.) and $\mathrm{KI}$ ( 1 eq.) were suspended in $50 \mathrm{~mL}$ of acetonitrile. The reaction mixture was heated in a microwave reactor ( $50 \mathrm{~W}$, reflux) for $1 \mathrm{~h}$. The solvent was evaporated in a vacuum, the residue suspended in ethyl acetate and washed three times with brine and saturated $\mathrm{NaHCO}_{3}$, the organic layer dried over anhydrous sodium sulphate, filtered and evaporated in a vacuum. The crude ligand was purified by automated flash chromatography on a pre-packed neutral alumina column (48 g).

\pm CDA-BPA: ( \pm )-trans-1,2-Diaminocyclohexane $(120.0 \mu \mathrm{L}, 1.0 \mathrm{mmol}), \mathrm{K}_{2} \mathrm{CO}_{3}(1658.4 \mathrm{mg}$, $12.0 \mathrm{mmol}), 2$-(chloromethyl)pyridine hydrochloride $(656.2 \mathrm{mg}, 4.0 \mathrm{mmol}), \mathrm{KI}(166.0 \mathrm{mg}$, $1.0 \mathrm{mmol})$. Automated flash chromatography $0 \rightarrow 5 \%$ dichloromethane in methanol $\left(R_{\mathrm{f}}=0.42\right.$, $5 \%$ dichloromethane in methanol). Yield: $303.0 \mathrm{mg}(0.6 \mathrm{mmol}, 63 \%)$, brown oil.

$(R, R)$-CDA-BPA: $(1 R, 2 R)-(-)-1,2-$ Diaminocyclohexane (114.2 $\mathrm{mg}, 1.0 \mathrm{mmol}), \mathrm{K}_{2} \mathrm{CO}_{3}$ (1658.4 mg, $12.0 \mathrm{mmol}), 2$-(chloromethyl)pyridine hydrochloride $(656.2 \mathrm{mg}, 4.0 \mathrm{mmol})$, KI (166.0 mg, $1.0 \mathrm{mmol})$. Automated flash chromatography $0 \rightarrow 5 \%$ dichloromethane in methanol. Yield: $337.5 \mathrm{mg}(0.7 \mathrm{mmol}, 71 \%)$, light brown powder. ${ }^{1} \mathrm{H}$ NMR $(300 \mathrm{MHz}$, $\left.\mathrm{CD}_{3} \mathrm{CN}\right) \delta: 8.39(\mathrm{~d}, J=4.7 \mathrm{~Hz}, 4 \mathrm{H}), 7.61(\mathrm{~d}, J=7.8 \mathrm{~Hz}, 4 \mathrm{H}), 7.55-7.41(\mathrm{~m}, 4 \mathrm{H}), 7.18-7.03$ $(\mathrm{m}, 4 \mathrm{H}), 3.70(\mathrm{~d}, J=14.3 \mathrm{~Hz}, 4 \mathrm{H}), 3.58(\mathrm{~d}, J=14.3 \mathrm{~Hz}, 4 \mathrm{H}), 2.85-2.66(\mathrm{~m}, 2 \mathrm{H}), 1.79-1.61(\mathrm{~m}$, $2 \mathrm{H}), 1.36-1.23(\mathrm{~m}, 1 \mathrm{H}), 1.23-1.00(\mathrm{~m}, 4 \mathrm{H}), 0.96-0.79(\mathrm{~m}, 1 \mathrm{H}) .{ }^{13} \mathrm{C} \mathrm{NMR}\left(75 \mathrm{MHz}, \mathrm{CD}_{3} \mathrm{CN}\right) \delta$ : 161.6, 149.5, 136.7, 124.5, 122.6, 60.8, 56.5, 26.8, 25.7. ESI-MS ( $\mathrm{m} / \mathrm{z}): 479.2\left(\mathrm{M}+\mathrm{H}^{+}, 100 \%\right)$.

\pm CDA-BQA: $\left( \pm\right.$ )-trans-1,2-Diaminocyclohexane $(70.5 \mu \mathrm{L}, 0.6 \mathrm{mmol}), \mathrm{K}_{2} \mathrm{CO}_{3}(970.2 \mathrm{mg}$, $7.0 \mathrm{mmol}$ ), 2-(chloromethyl)quinoline hydrochloride (500.0 mg, $2.3 \mathrm{mmol}), \mathrm{KI}(96.3 \mathrm{mg}$, $0.6 \mathrm{mmol})$. No further purification was required, $\left(R_{\mathrm{f}}=0.28\right.$, ethyl acetate:hexane 1:1). Yield: $372.3 \mathrm{mg}(0.5 \mathrm{mmol}, 94 \%)$, yellow powder.

$(R, R)$-CDA-BQA: $(1 R, 2 R)-(-)-1,2$-Diaminocyclohexane $(44.5 \mathrm{mg}, 0.4 \mathrm{mmol}), \mathrm{K}_{2} \mathrm{CO}_{3}$ (651.6 mg, $4.7 \mathrm{mmol}), 2$-(chloromethyl)quinoline hydrochloride (378.9 mg, $1.6 \mathrm{mmol}$ ), KI $(64.7 \mathrm{mg}, 0.4 \mathrm{mmol})$. Automated flash chromatography $10 \rightarrow 40 \%$ ethyl acetate in hexane. Yield: $202.3 \mathrm{mg}(0.3 \mathrm{mmol}, 76 \%)$, light yellow powder. ${ }^{1} \mathrm{H} \mathrm{NMR}\left(300 \mathrm{MHz}, \mathrm{CDCl}_{3}\right) \delta: 7.99$ $(\mathrm{d}, J=8.3 \mathrm{~Hz}, 4 \mathrm{H}), 7.91(\mathrm{~d}, J=8.5 \mathrm{~Hz}, 4 \mathrm{H}), 7.77(\mathrm{~d}, J=8.5 \mathrm{~Hz}, 4 \mathrm{H}), 7.72-7.59(\mathrm{~m}, 8 \mathrm{H})$, 7.52-7.41 (m, 4H), $4.01(\mathrm{~d}, J=14.1 \mathrm{~Hz}, 4 \mathrm{H}), 3.85(\mathrm{~d}, J=14.1 \mathrm{~Hz}, 4 \mathrm{H}), 3.00-2.81(\mathrm{~m}, 2 \mathrm{H})$, 2.49-2.27 (m, 2H), 1.88-1.69 (m, 2H), 1.25-0.94 (m, 4H). ${ }^{13} \mathrm{C} \mathrm{NMR}\left(75 \mathrm{MHz}, \mathrm{CDCl}_{3}\right) \delta: 161.3$, $147.7,135.8,129.3,129.1,127.6,127.4,126.1,122.2,60.7,56.6,29.8,26.0,24.4$. ESI-MS $(m / z)$ : $679.4\left(\mathrm{M}+\mathrm{H}^{+}, 100 \%\right)$.

$\mathrm{Fe}^{\mathrm{II}}\left(\mathrm{CDA}_{\mathrm{BQA}}{ }^{*}\right)(5)$ : Ligand $\pm \mathrm{CDA}-\mathrm{BQA}(14.2 \mathrm{mg}, 0.02 \mathrm{mmol})$ and $\mathrm{Fe}\left(\mathrm{CF}_{3} \mathrm{SO}_{3}\right)_{2}$ ( $7.4 \mathrm{mg}, 0.02 \mathrm{mmol}$ ) were dissolved in dry acetonitrile and mixed. The reaction vessel was placed in a tank with dry diethyl ether for vapour diffusion. The complex preparation was performed in a drybox in an atmosphere of argon. After 1 day, crystals suitable for single crystal X-ray diffraction were obtained. UV-Vis [MeCN $=$ acetonitrile] $\left[\lambda_{\max }, \mathrm{nm}\right.$ $\log \varepsilon]=203$ (5.03), 231 (4.78), 307 (4.13). FT-IR bands $\left(\mathrm{KBr}\right.$ pellet $\left.\mathrm{cm}^{-1}\right): 3429 \mathrm{~m}, 3068$ w, 2933 w, 2859 w, 1701 s, 1653 s, 1600 w, 1279 s, 1166 s, 1029 s, 784 w, 667 m, 638 m, 522 w. Anal Calcd for $\mathrm{C}_{48} \mathrm{H}_{42} \mathrm{~F}_{6} \mathrm{FeN}_{6} \mathrm{O}_{6} \mathrm{~S}_{2}$ : C, 55.82; H, 4.10; N, 8.14. Found: C, 55.79; $\mathrm{H}, 4.15 ; \mathrm{N}, 8.19$. X-ray: Chemical formula: $\mathrm{C}_{50} \mathrm{H}_{45} \mathrm{~F}_{6} \mathrm{FeN}_{7} \mathrm{O}_{6} \mathrm{~S}_{2}$, Formula weight: 1073.90, Crystal system: orthorhombic, Space group: Cmca, $a(\AA): 19.7874(9), b(\AA): 42.5557(15), c$ (Å): 12.4013(4), Volume $\left(\AA^{3}\right)$ : 10442.7(7), Z: 8, Calc. density $\left(\mathrm{g} \mathrm{cm}^{-1}\right)$ : 1.366, Temperature 
(K): 293(2), Abs. coeff. (mm $\left.{ }^{-1}\right): 3.715, F(000): 4432$, Obs. reflections: 5532, Goodness-of-fit: 1.055, $R_{1}: 0.0761, w \mathrm{R}_{2}: 0.2287\left(w=1 / \sigma^{2}\left(F_{\mathrm{o}}{ }^{2}\right)+(0.1721 P)^{2}+1.4205 P\right]$ and $\left.P=\left(F_{o}{ }^{2}+2 F_{c}{ }^{2}\right) / 3\right)$. CCDC deposit number 2082080 contains the supplementary crystallographic data for this paper. These data can be obtained free of charge via http://www.ccdc.cam.ac.uk/conts/ retrieving.html (accessed on 30 April 2021) (or from the Cambridge Crystallographic Data Centre, 12, Union Road, Cambridge CB2 1EZ, UK; fax: +44 1223 336033) (Table S1).

Catalytic oxidation of ethylbenzene was carried out under thermostatic $(273 \mathrm{~K})$ conditions. In a typical reaction, $500 \mu \mathrm{L}$ of TBHP (diluted from $70 \%$ TBHP) solution in $\mathrm{CH}_{3} \mathrm{CN}$ was delivered by a syringe pump in air to a stirred solution $(1 \mathrm{~mL})$ of 6 catalysts, and ethylbenzene inside a vial. The final concentrations were $2 \mathrm{mM}$ catalyst 6, $50 \mathrm{mM}(100$, $200 \mathrm{mM}$ ) oxidant, and $500 \mathrm{mM}$ substrate. The mixture was stirred for $15 \mathrm{~min}$. The products were identified by GC analysis, and their yields were determined by comparison with authentic compounds using bromobenzene $\left(25.00 \times 10^{-3} \mathrm{M}\right)$ as an internal standard in the reactions.

Complex $6\left(2.00 \times 10^{-3} \mathrm{M}\right)$ was dissolved in acetonitrile $(2 \mathrm{~mL})$, then iodosobenzene $\left(16.00 \times 10^{-3} \mathrm{M}\right)$ and ethylbenzene $\left(1500 \times 10^{-3} \mathrm{M}\right)$ were added to the solution in $\mathrm{CH}_{3} \mathrm{CN}$ at $273 \mathrm{~K}$. The mixture was stirred for $3 \mathrm{~h}$ and the products were identified by GC analysis, and their yields were determined by comparison with authentic compounds using bromobenzene $\left(4.00 \times 10^{-3} \mathrm{M}\right)$ as an internal standard in the reactions. Enantiomeric excess was determined with GC analysis on a chiral column: $(e e=[R]-[S]) /([R]+[S])$.

Catalytic oxidation of flavanone was carried out under thermostatic $(298 \mathrm{~K})$ conditions. In a typical reaction, $5.8 \mathrm{mg} 2(5 \mathrm{mM})$ and $33.6 \mathrm{mg}$ flavanone $(100 \mathrm{mM})$ was dissolved in $1 \mathrm{~mL} \mathrm{CH}_{3} \mathrm{CN}$, and $169 \mathrm{mg} \mathrm{mCPBA}(500 \mathrm{mM})$ in $500 \mu \mathrm{L} \mathrm{CH}{ }_{3} \mathrm{CN}$ was delivered by syringe pump to a stirred solution. After syringe pump addition ( $5 \mathrm{~min}$ the solution was stirred for $5 \mathrm{~min}$ and a known amount of $\mathrm{PhBr}(0.315 \mathrm{mmol})$ was added as an internal standard. The iron complex was removed by passing the reaction mixture through a silica column followed by elution with ethyl acetate. The products (1,3-dione (D) and flavone) were identified by GC/MS and confirmed by comparison with authentic samples. Flavone is commercially available and it was purchased from Sigma-Aldrich. 1-(2-hydroxy-phenyl)-3phenyl-propane-1,3-dione (D): o-Benzoyloxyacetophenone has been prepared by the action of benzoyl chloride on a pyridine solution of o-hydroxyacetophenone. Its rearrangement to 1-(2-hydroxy-phenyl)-3-phenyl-propane-1,3-dione (D) by alkali has been described [57]. (F) $m / z$ : 222 (85.92\%), 194 (58.9\%), 165 (18\%) 120 (100\%), 92 (95,2\%). 63 (35.3\%). 1,3-dione (D): $m / z$ : $240(15.1 \%), 223(8.3 \%), 121(25.2 \%), 120(7.3 \%), 106$ (7.2\%), $105(100 \%), 77(30 \%)$, $69(6.0 \%), 65$ (9.3\%), $51(4.5 \%), 39(8.3 \%)$.

Stoichiometric reactions were carried out under thermostatic conditions at $10^{\circ} \mathrm{C}$ in $1 \mathrm{~cm}$ quartz cuvettes. In a typical experiment, $\left[\mathrm{Fe}^{\mathrm{II}}(\mathrm{Bn}-\mathrm{TPEN})\left(\mathrm{CH}_{3} \mathrm{CN}\right)\right]^{2+}\left(2 \times 10^{-3} \mathrm{M}\right)$ was dissolved in acetonitrile $\left(\mathrm{CH}_{3} \mathrm{CN}-\mathrm{TFE}\right)\left(2.0 \mathrm{~cm}^{3}\right)$, then iodosobenzene $\left(4 \times 10^{-3} \mathrm{mM}\right)$ was added to the solution. The mixture was stirred for $50 \mathrm{~min}$ then excess iodosobenzene was removed by filtration. Flavanone $(50 \mathrm{mM})$ was added to the solution and the reaction was monitored by UV-Vis spectrophotometer (Agilent 8453) at $739 \mathrm{~nm}\left(\varepsilon=450 \mathrm{M}^{-1} \mathrm{~cm}^{-1}\right)$.

\section{Conclusions}

In conclusion, we previously found that N4Py-based iron(II) complexes capable of carrying out 2,3-desaturation of flavanone via 2-hydroxyflavanone intermediate formation can act as a functional flavone synthase model. As a continuity of this study, efforts have been made to enhance the catalytic activity by the use of TPEN-type ligands and investigate the role and effect of the metal cofactor through manganese and iron complexes with the same ligand framework. Comparing the reactions of $\left[\mathrm{Fe}^{\mathrm{IV}}(\mathrm{O})(\mathrm{Bn}-\mathrm{TPEN})\right]^{2+}(9)$ and $\left[\mathrm{Mn}^{\mathrm{IV}}(\mathrm{O})(\mathrm{Bn}-\mathrm{TPEN})\right]^{2+}(\mathbf{1 0})$ towards flavanone under the same conditions, a 3.5-fold difference in reaction rate was observed in favour of iron, and this value is three orders of magnitude higher than that was observed for the previously published $\left[\mathrm{Fe}^{\mathrm{IV}}(\mathrm{O})\left(\mathrm{N} 2 \mathrm{Py} 2 \mathrm{Q}^{*}\right)\right]^{2+}$ species. The relative reactivity of oxoiron(IV) complexes is in the order of $\left[\mathrm{Fe}^{\mathrm{IV}}(\mathrm{O})(\mathrm{CDA}\right.$ $\left.\left.\mathrm{BPA}^{*}\right)\right]^{2+}(\mathbf{1 1})>\left[\mathrm{Fe}^{\mathrm{IV}}(\mathrm{O})(\mathrm{Bn}-\mathrm{TPEN})\right]^{2+}(\mathbf{9})>\left[\mathrm{Fe}^{\mathrm{IV}}(\mathrm{O})\left(\mathrm{N} 2 \mathrm{Py}^{2} \mathrm{Q}^{*}\right)\right]^{2+}>\left[\mathrm{Fe}^{\mathrm{IV}}(\mathrm{O})(\mathrm{N} 4 \mathrm{Py})\right]^{2+}$ 
$>\left[\mathrm{Fe}^{\mathrm{IV}}(\mathrm{O})\left(\mathrm{N} 4 \mathrm{Py} \mathrm{y}^{*}\right)\right]^{2+}(7)$, which is consistent with our catalytic results, and shows that addition of cyclohexanediamine as the chiral element successfully lead to increase in the catalytic activity. Although we have reported the first example of efficient flavanone oxidation by iron and manganese complexes, detailed studies are underway to elucidate the mechanisms of flavone formation.

Supplementary Materials: The following are available online. Figure S1: Ligands $\mathbf{1 a}( \pm$ cda-bpa $)-\mathbf{2 b}$ ( \pm cda-bqa); Figure S2: Packing of $\left[\mathrm{Fe}^{\mathrm{II}}\left(\mathrm{CDA}-\mathrm{BQA}^{*}\right)\right]^{2+}$ complexes in rac-5. Individual enantiomers are shown in red and blue colours, respectively. Triflate anions and acetonitrile molecules are omitted for clarity; Table S1: Experimental data for the X-ray diffraction studies; Table S2: The calculated $k_{o b s}$ values in the reaction of $\mathbf{9}$ and flavanone in MeCN; Table S3: The calculated $k_{o b s}$ values in the reaction of $\mathbf{9}$ and flavanone in MeCN/TFE; Table S4: The calculated $k_{o b s}$ values in the reaction of $\mathbf{1 1}$ and flavanone in MeCN; Table S5: The calculated $k_{o b s}$ values in the reaction of $\mathbf{1 0}$ and flavanone in $\mathrm{MeCN} / \mathrm{TFE}$.

Author Contributions: Conceptualization, J.K. and S.I.K.; resources, D.L.-B., N.P.J., B.I.M., and B.P.; writing—original draft preparation, J.K., writing-review and editing, J.K. All authors have read and agreed to the published version of the manuscript.

Funding: Financial support of the GINOP-2.3.2-15-2016-00049 are gratefully acknowledged. Part of the work was supported by the Croatian Science Foundation (IP-2014-09-1461), and CAT Pharma (KK.01.1.1.04.0013), a project co-financed by the Croatian Government and the European Union through the European Regional Development Fund-the Competitiveness and Cohesion Operational Programme.

Data Availability Statement: Not available.

Conflicts of Interest: The authors declare no conflict of interest.

\section{References}

1. Singh, M.; Kaur, M.; Silakari, O. Flavones: An important scaffold for medicinal chemistry. Eur. J. Med. Chem. 2014, 84, 206-239. [CrossRef] [PubMed]

2. Middleton, E.; Kandaswami, C., Jr.; Theoharides, T.C. The effects of plant flavonoids on mammalian cells: Implications for inflammation, heart disease, and cancer. Pharmacol. Rev. 2000, 52, 673-751. [PubMed]

3. Kromhout, D. Diet and cardiovascular diseases. J. Nutr. Health Aging 2001, 5, 144-149. [PubMed]

4. Tabak, C.; Arts, I.C.; Smit, H.A.; Heedrik, D.; Kromhout, D. Chronic obstructive pulmonary disease and intake of catechins, flavonols, and flavones: The MORGAN Study. Am. J. Respir. Crit. Care Med. 2001, 164, 61-64. [CrossRef]

5. Ross, J.A.; Kansum, C.M. Dietary flavonoids: Bioavailability, metabolic effects, and safety. Annu. Rev. Nutr. 2002, 22, 19-34. [CrossRef]

6. Manach, C.; Mazur, A.; Scalbert, A. Polyphenols and prevention of cardiovascular diseases. Curr. Opin. Lipidol. 2003, 16, 77-84. [CrossRef]

7. Arts, I.C.; Hollman, P.C. Polyphenols and disease risk in epidemiologic studies. Am. J. Clin. Nutr. 2005, 81, 317-325. [CrossRef]

8. Havsteen, B.H. The biochemistry and medical significance of the flavonoids. Pharmacol. Ther. 2002, 96, 67-202. [CrossRef]

9. Doshi, A.G.; Soni, P.A.B.; Ghiya, J. Oxidation of 2'-hydroxychalcones. Indian J. Chem. 1986, 25B, 759.

10. Mahal, H.S.; Rai, H.S.; Venkataraman, K. Synthetical experiments in the chromone group. Part XVI. Chalkones and flavanones and their oxidation to flavones by means of selenium dioxide. J. Chem. Soc. 1935, 866-868. [CrossRef]

11. Shanker, C.G.; Mallaiah, B.V.; Srimannarayana, G. Dehydrogenation of chromanones and flavanones by 2,3-dichloro-5,6-dicyano1,4-benzoquinone (DDQ)- A facile method for the synthesis of chromanones and flavones. Synthesis 1983, 4, 310-311. [CrossRef]

12. Singh, O.V.; Kapoor, R.P. Dehydrogenation of flavanones to flavones using thallium(III) acetate (TTA). Tetrahedron Lett. 1990, 31, 1459-1462. [CrossRef]

13. Singh, O.V.; Muthukrishnan, M.; Gopan, R. Manganese(III) acetate mediated oxidation of flavanones: A facile synthesis of flavones. Synth. Commun. 2005, 35, 2723-2728. [CrossRef]

14. Ko, T.P.; Day, J.; Malkin, A.J.; McPherson, A. Structure of orthorhombic crystals of beef liver catalase. Acta Crystallogr. 1999, D55, 1383-1394. [CrossRef]

15. Ivancich, A.; Jouve, H.M.; Sartor, B.; Gaillard, J. EPR investigation of compound I in Proteus mirabilis and bovin liver catalases: Formation of porphyrin and tyrosyl radical intermediates. Biochemistry 1997, 36, 9356-9364. [CrossRef]

16. Martens, S.; Forkmann, G. Genetic control of flavone synthase II activity in flowers of gerbera hybrids. Phytochemistry 1998, 49 , 1953-1958. [CrossRef]

17. Akashi, T.; Aoki, T.; Ayabe, S.I. Cloning and functional expression of a cytochrome P450 cDNA encoding 2-hydroxyisoflavanone synthase involved in biosynthesis of the isoflavonoid skeleton in licorice. Plant Physiol. 1999, 121, 821-828. [CrossRef] 
18. Akashi, T.; Aoki, T.; Ayabe, S.I. Identification of a cytochrome P450 cDNA encoding (2S)-flavanone 2-hydroxylase of licorice (Glycyrrhiza echinata L.; Fabaceae) which represents licodione synthase and flavone synthase II. FEBS Lett. 1998, 431, 287-290. [CrossRef]

19. Zhang, J.; Subramanian, S.; Zhang, Y.; Yu, O. Flavone synthases from Medicago truncatula are flavanone-2-hydroxylases and are important for nodulation. Plant Physiol. 2007, 144, 741-751. [CrossRef]

20. Du, Y.; Chu, H.; Wang, M.; Chu, I.K.; Lo, C. Identification of flavone phytoalexins and a pathogen-inducible flavone synthase II gene (SbFNSII) in sorghum. J. Exp. Bot. 2010, 61, 983-994. [CrossRef]

21. Kappock, T.J.; Caradonna, J.P. Pterin-dependent amino acid hydroxylases. Chem. Rev. 1996, 96, 2659-2756. [CrossRef] [PubMed]

22. Elkins, J.M.; Ryle, M.J.; Clifton, I.J.; Dunning Hottop, J.C.; Lloyd, J.S.; Burzlaff, N.I.; Baldwin, J.E.; Hausinger, R.P.; Roach, P.L. X-ray Crystal structure of escherichia coli taurine $/ \alpha$-ketoglutarate dioxygenase complexed to ferrous iron and substrates. Biochemistry 2002, 41, 5185-5192. [CrossRef] [PubMed]

23. Costas, M.; Mehn, M.P.; Jensen, M.P.; Que, L., Jr. Dioxygen Activation at mononuclear nonheme iron active sites: Enzymes, models, and intermediates. Chem. Rev. 2004, 104, 939-986. [CrossRef] [PubMed]

24. Nam, W. Dioxygen activation by metalloenzymes and models. Acc. Chem. Res. 2007, 40, 465. [CrossRef]

25. Gebhardt, Y.; Witte, S.; Forkmann, G.; Lukac ${ }^{`}$ in, R.; Matern, U.; Martens, S. Molecular evolution of flavonoid dioxygenases in the family Apiaceae. Phytochemistry 2005, 66, 1273-1284. [CrossRef]

26. Gebhardt, Y.H.; Witte, S.; Steuber, H.; Matern, U.; Martens, S. Evolution of flavone synthase I from parsley flavanone 3 $\beta$ hydroxylase by sitedirected mutagenesis. Plant Physiol. 2007, 144, 1442-1454. [CrossRef]

27. Lee, Y.J.; Kim, J.H.; Kim, B.G.; Lim, Y.; Ahn, J.H. Characterization of flavone synthase I from rice. BMB Rep. $2008,41,68-71$. [CrossRef]

28. Britsch, L. Purification and characterization of flavone synthase I, 2- oxoglutarate-dependent desaturase. Arch. Biochem. Biophys. 1990, 282, 152-160. [CrossRef]

29. Fliegmann, J.; Furtwangler, K.; Malterer, G.; Cantarello, C.; Schüler, G.; Ebel, J.; Mithöfer, A. Flavone synthase II (CYP93B16) from soybean (Glycine max L.). Phytochemistry 2010, 71, 508-514. [CrossRef]

30. Martens, S.; Forkmann, G.; Britsch, L.; Wellmann, F.; Matern, U.; Lukačin, R. Divergent evolution of flavonoid 2-oxoglutaratedependent dioxygenases in parsley. FEBS Lett. 2003, 544, 93-98. [CrossRef]

31. Du, J.; Zhang, J.; Zhu, J.; Xia, C.; Sun, W. Synthesis, characterization, and reactivity of a chiral Fe(IV)-oxo complex bearing an L-proline derived aminopyridine ligand. New J. Chem. 2018, 42, 8315-8319. [CrossRef]

32. Duboc-Toia, C.; Ménage, S.; Ho, R.Y.N.; Que, L., Jr.; Lambeaux, C.; Fontecave, M. Enantioselective sulfoxidation as a probe for a metal-based mechanism in $\mathrm{H}_{2} \mathrm{O}_{2}$-dependent oxidations catalyzed by a diiron complex. Inorg. Chem. 1999, 38, $1261-1268$. [CrossRef]

33. Lakk-Bogáth, D.; Csonka, R.; Speier, G.; Reglier, M.; Simaan, A.J.; Naubron, J.V.; Giorgi, M.; Lázár, K.; Kaizer, J. Formation, characterization, and reactivity of a nonheme oxoiron(IV) complex derived from the chiral pentadentate ligand asN4Py. Inorg. Chem. 2016, 55, 10090-10093. [CrossRef]

34. Meena, B.I.; Lakk-Bogáth, D.; Kripli, B.; Speir, G.; Kaizer, J. Kinetics and mechanism of epoxidation of olefins by chiral tetrapyridyl oxoiron(IV) complex. Polyhedron 2018, 151, 141-145. [CrossRef]

35. Turcas, R.; Lakk-Bogáth, D.; Speier, G.; Kaizer, J. Kinetics and enantioselectivity of the Baeyer-Villiger oxidation of cyclohexanones by chiral tetrapyridyl oxoiron(IV) complex. Inorg. Chem. Commun. 2018, 92, 141-144. [CrossRef]

36. Lakk-Bogáth, D.; Kripli, B.; Meena, B.I.; Speier, G.; Kaizer, J. Catalytic and stoichiometric C-H oxidation of benzylalcohols and hydrocarbons mediated by nonheme oxoiron(IV) complex with chiral tetrapyridyl ligand. Inorg. Chem. Commun. 2019, 104, 165-170. [CrossRef]

37. Kaizer, J.; Klinker, E.J.; Oh, N.Y.; Rohde, J.-U.; Song, W.J.; Stubna, A.; Kim, J.; Münck, E.; Nam, W.; Que, L., Jr. Nonheme Fe ${ }^{I V} \mathrm{O}$ complexes that can oxidize th C-H bonds of cyclohexane at room temperature. J. Am. Chem. Soc. 2004, 126, 472-473. [CrossRef]

38. Klinker, E.J.; Kaizer, J.; Brennessel, W.B.; Woodrum, N.L.; Cramer, C.J.; Que, L., Jr. Structures of nonheme oxoiron(IV) complexes from X-ray crystallography, NMR spectroscopy, and DFT calculations. Angew. Chem. 2005, 117, 3756-3760. [CrossRef]

39. Kripli, B.; Garda, Z.; Sólyom, B.; Tircsó, G.; Kaizer, J. Formation, stability and catalase-like activity of mononuclear manganese(II) and oxomanganese complexes in protic and aprotic solvents. New J. Chem. 2020, 44, 5545-5555. [CrossRef]

40. Wu, X.; Seo, M.S.; Davis, K.M.; Lee, Y.-M.; Chen, J.; Cho, K.-B.; Pushkar, Y.N.; Nam, W. A highly reactive mononuclear non-heme manganese(IV)-oxo complex that can activate the strong C-H bonds of alkanes. J. Am. Chem. Soc. 2011, 133, 20088-20091. [CrossRef]

41. McCuster, J.K.; Toftlund, H.; Rheingold, A.L.; Hendrickson, D.N. Ligand conformational changes affecting 5T2-fwdarw. 1A1 intersystem crossing in a ferrous complex. J. Am. Chem. Soc. 1993, 115, 1797-1804. [CrossRef]

42. Kaizer, J.; Costas, M.; Que, L., Jr. A dramatic push effect on the homolysis of $\mathrm{Fe}^{\mathrm{III}}(\mathrm{OOR})$ intermediates to form non-heme $\mathrm{Fe}^{\mathrm{IV}}=\mathrm{O}$ vomplexes. Angew. Chem. 2003, 115, 3799-3801. [CrossRef]

43. McDonald, A.R.; Que, L., Jr. High-valent nonheme iron-oxo complexes: Synthesis, structure, and spectroscopy. Coord. Chem. Rev. 2013, 257, 414-428. [CrossRef]

44. Krebs, C.; Fujimori, D.G.; Walsh, C.T.; Bollinger, J.M., Jr. Non-heme Fe(IV)-oxo intermediates. Acc. Chem. Res. 2007, 40, 484-492. [CrossRef]

45. Que, L., Jr. The Road to Non-heme oxoferryls and beyond. Acc. Chem. Res. 2007, 40, 493-500. [CrossRef] 
46. Turcas, R.; Kripli, B.; Attia, A.A.A.; Lakk-Bogáth, D.; Speier, G.; Giorgi, M.; Silaghi-Dumitrescu, R.; Kaizer, J. Catalytic and stoichiometric flavanone oxidation by nonheme oxoiron(IV) complexes as flavone synthase mimics: Kinetic, mechanistic and computational studies. Dalton Trans. 2018, 47, 14416-14420. [CrossRef]

47. Mikata, Y.; Sato, Y.; Takeuchi, S.; Kuroda, Y.; Konno, H.; Iwatsuki, S. Quinoline-based fluorescent zinc sensors with enhanced fluorescence intensity, $\mathrm{Zn} / \mathrm{Cd}$ selectivity and metal binding affinity by conformational restriction. Dalton Trans. 2013, 42, 9688-9698. [CrossRef]

48. Mikata, Y.; Wakamatsu, M.; Kawamura, A.; Yamanaka, N.; Yano, S.; Odani, A.; Morihiro, K.; Tamotsu, S. Methoxy-substituted TQEN family of fluorescent zinc sensors. Inorg. Chem. 2006, 45, 9262-9268. [CrossRef]

49. Tamura, M.; Urano, Y.; Kikuchi, K.; Higuchi, T.; Hirobe, M.; Nagano, T. Superoxide dismutase activity of iron(II)TPEN complex and its derivatives. Chem. Pharm. Bull. 2000, 48, 1514-1518. [CrossRef]

50. Balland, V.; Banse, F.; Anxolabéhère-Mallart, E.; Nierlich, M.; Girerd, J.-J. Iron complexes containing the ligand N,N'-bis(6-methyl2-pyridylmethyl)- $N, N^{\prime}$-bis(2-pyridylmethyl)ethane-1,2-diamine: Structural, spectroscopic, and electrochemical studies, reactivity with hydrogen peroxide and the formation of a low-spin Fe-OOH complex. Eur. J. Inorg. Chem. 2003, 2529-2535. [CrossRef]

51. Sénéchal-David, K.; Buron, C.; Ségaud, N.; Rebilly, J.-N.; Dos Santos, A.; Farjon, J.; Guillot, R.; Herrero, C.; Inceoglu, T.; Banse, F. Non-heme Fe(II) diastereomeric complexes bearing a hexadentate ligand:unexpected consequences on the spin state and oxidation catalytic properties. Chem. A Eur. J. 2019, 25, 12405-12411. [CrossRef] [PubMed]

52. Chen, G.; Espinosa-Perez, G.; Zentella-Dehesa, A.; Silaghi-Dumitrescu, I.; Lara-Ochoa, F. (Tetrakis(2-pyridylmethyl)ethylenediamine) iron(II) perchlorate. Study of density functional methods. Inorg. Chem. 2000, 39, 3440-3448. [CrossRef] [PubMed]

53. Andreini, C.; Cavallaro, G.; Lorenzini, S. FindGeo: A tool for determining metal coordination geometry. Bioinformatics 2012, 28, 1658-1660. [CrossRef] [PubMed]

54. Paine, T.K.; Costas, M.; Kaizer, J.; Que, L., Jr. Oxoiron(IV) complexes of the tris(2-pyridylmethyl)amine ligand family: Effect of pyridine a-substituents. J. Biol. Inorg. Chem. 2006, 11, 272-276. [CrossRef] [PubMed]

55. Lakk-Bogáth, D.; Speier, G.; Kaizer, J. Comparison of the stability and reactivity of achiral versus chiral nonheme oxoiron(IV) complexes supported by pentadentate N5 ligands in oxygen-atom and hydrogen-atom transfer reactions. Inorg. Chem. Commun. 2019, 107, 107446. [CrossRef]

56. Cho, K.-B.; Hirao, H.; Shaik, S.; Nam, W. To rebound or dissociate? This is the mechanistic question in C-H hydroxylation by heme and nonheme metal-oxo complexes. Chem. Soc. Rev. 2016, 45, 1197-1210. [CrossRef] [PubMed]

57. Wheeler, T.S. Flavone. Org. Synth. 1952, 32, 72-76. [CrossRef] 